Florida International University FIU Digital Commons

7-23-1998

\title{
Determining interspecific interactions between the dominant macrophytes of tropical, atlantic seagrass meadows
}

Braxton C. Davis

Florida International University

DOI: $10.25148 /$ etd.FI14062209

Follow this and additional works at: https://digitalcommons.fiu.edu/etd

Part of the Biology Commons

\section{Recommended Citation}

Davis, Braxton C., "Determining interspecific interactions between the dominant macrophytes of tropical, atlantic seagrass meadows" (1998). FIU Electronic Theses and Dissertations. 2743.

https://digitalcommons.fiu.edu/etd/2743 


\section{FLORIDA INTERNATIONAL UNIVERSITY \\ Miami, Florida}

DETERMINING INTERSPECIFIC INTERACTIONS BETWEEN

THE DOMINANT MACROPHYTES OF TROPICAL, ATLANTIC SEAGRASS MEADOWS.

A thesis submitted in partial satisfaction of the

requirements for the degree of

MASTER OF SCIENCE

IN

BIOLOGY

by

Braxton C. Davis 
To: Dean Arthur W. Herriott

College of Arts and Sciences

This thesis, written by Braxton C. Davis, and entitled DETERMINING INTERSPECIFIC INTERACTIONS BETWEEN THE DOMINANT MACROPHYTES OF TROPICAL, ATLANTIC SEAGRASS MEADOWS, having been approved in respect to style and intellectual content, is referred to you for judgment.

We have read this thesis and recommend that it be approved.

Steven Miller

Daniel L. Childers

James W. Fourqurean, Major Professor

Date of Defense: July 23, 1998

The thesis of Braxton C. Davis is approved.

Dean Arthur W. Herriott

College of Arts and Sciences

Dr. Richard L. Campbell

Dean of Graduate Studies

Florida International University, 1998 


\section{ACKNOWLEDGEMENTS}

I wish to thank the members of my committee for their helpful comments and patience. I also want to thank the members of the lab, who contributed both advice and help in the field: Cassie Furst, Brian Machovina, Patty Mumford, Craig Rose, Leanne Rutten, and Allan Willsie. Many others helped with fieldwork: Jeff Absten, Steve Davis, Susan Dailey, Rob Daoust, Nick Oehm, Luz Romero, and Boris Wenglowski, thanks again for the assistance. Finally, a special thanks to my wife, who married me in the middle of it all without any assurance that I would graduate, thank you for all of the support in the lab, in the field, and at home. 


\section{ABSTRACT OF THE THESIS \\ DETERMINING INTERSPECIFIC INTERACTIONS BETWEEN THE DOMINANT MACROPHYTES OF TROPICAL, ATLANTIC SEAGRASS MEADOWS.}

by

Braxton C. Davis

Florida International University, 1998

Miami, Florida

Professor James W. Fourqurean, Major Professor

Though often suggested in seagrass literature, interactions between abundant rhizophytic macroalgae and coexisting tropical seagrasses have not been directly examined. Based on a competitive interaction hypothesis, I first tested for negative correlations between species densities over large and small spatial scales. After finding negative correlations, I tested experimentally for a competitive interaction by manipulating the relative densities of the locally dominant seagrass and a representative macroalga. Based on significant growth responses to density manipulations, I demonstrated that these species are likely competing for some limiting resource, possibly nitrogen. This study contributes to a better understanding of processes that dictate community composition in these systems. 


\section{TABLE OF CONTENTS}

CHAPTER

PAGE

L. INTRODUCTION.

Dominant Macrophytes in Tropical Atlantic Seagrass Meadows..........3

Morphologies, Life Histories, and Resource Acquisition Strategies.....4

Possible Species Interactions.......................................................12

A Spatial Competition Hypothesis..............................................13

A Two-Part Study....................................................................15

Part I: Observational Data.........................................................15

Part II: Field Experiment.......................................................20

II. MACROPHYTE DISTRIBUTION WITHIN THE FLORIDA KEYS NATIONAL MARINE SANCTUARY: DETERMINING LARGE AND SMALL-SCALE SPATIAL PATTERNS..............................21

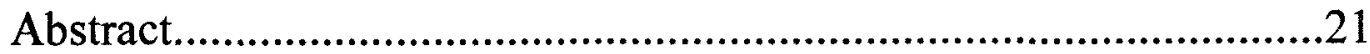

Large-scale Abundance Distributions............................................23

Small-scale Density Patterns......................................................24

Materials and Methods............................................................29

Large-scale Spatial Analysis.....................................................31

Small-scale Spatial Analysis...................................................31

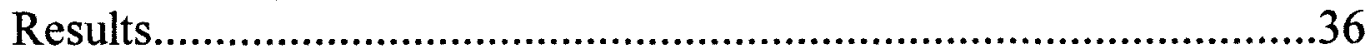

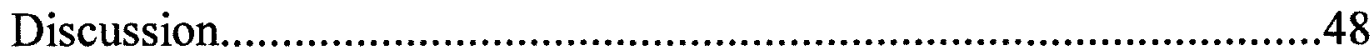

III. DETERMINING SPECIES INTERACTIONS BETWEEN THE TROPICAL ALGA, HALIMEDA INCRASSATA, AND THE SEAGRASS, THALASSIA TESTUDINUM...................................53

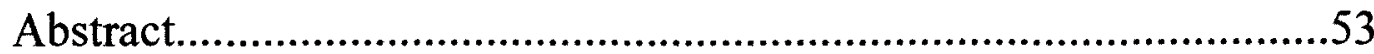

Materials and Methods.........................................................58

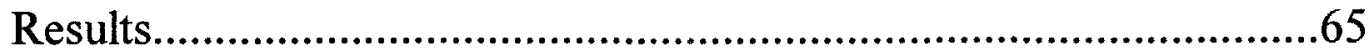

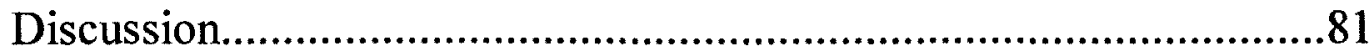

IV. CONCLUSIONS............................................................................85

LIST OF REFERENCES.................................................................87 


\section{LIST OF TABLES}

Table

Page

1. Relative seagrass life expectancies and growth rates.......................

2. Correlation matrix of seagrass and macroalgal densities..................46

3. Correlation matrix of seagrass and macroalgal densities.................47

4. Experimental design showing number of plots per treatment..........59

5. Comparison of net production by individual thalli and shoots........68

6. ANOVA results for growth rate comparisons, $H$. incrassata.........70

7. ANOVA results for growth rate comparisons, $H$. incrassata.........70

8. ANOVA results for dry weight comparisons, $H$. incrassata..........72

9. ANOVA results for dry weight comparisons, $H$. incrassata..........72

10. ANOVA results for production rate comparisons, T. testudinum..76

11. ANOVA results for 1.a. production comparisons, T. testudinum...77

12. ANOVA results for dry weight comparisons, T. testudinum..........78

13. ANOVA results for leaf tissue $\mathrm{C}: \mathrm{N}$ comparisons, T. testudinum...79

14. ANOVA results for substrate-level irradiance comparisons...........80 


\section{LIST OF FIGURES}

Figure

Page

1. Hypothetical seagrass community recolonization sequence...........18

2. Cross-section of idealized blowout...........................................18

3. Idealized model of tropical seagrass community development.......26

4. Cross-section of idealized blowout.........................................26

5. Hypothetical model of seagrass species zonation patterns............27

6. Model of predicted sequence of disturbance recolonization..........28

7. Sampling stations used for large-scale spatial analysis..................30

8. Blowout survey locations used for small-scale spatial analysis......33

9. Positioning of transects around disturbances...............................34

10. Thalassia testudinum abundance score distributions....................37

11. Syringodium filiforme abundance score distributions..................38

12. Calcareous green macroalgal abundance distributions..................39

13. Large-scale correlation analysis of species abundances...............40

14. Species distributions around a blowout disturbance....................42

15. Species distributions around a blowout disturbance.....................43

16. Species distributions around a blowout disturbance....................44

17. Macrophyte recolonization following blowout disturbances........45

18. Average growth rates versus treatment, Halimeda incrassata......69

19. Average above-ground dry weight vs. treatment, $H$. incrassata....71

20. Average production rates vs. treatment, Thalassia testudinum......76

21. Leaf area production rates vs. treatment, $T$. testudinum ................77

22. Average above-ground dry weight vs. treatment, T. testudinum....78

23. Average leaf tissue $\mathrm{C}: \mathrm{N}$ versus treatment, $T$. testudinum .............79

24. Average canopy and substrate-level irradiance vs. treatment........80 


\section{Chapter One}

\section{Introduction}

Tropical seagrass ecosystems are increasingly well-studied as their importance in primary production, water quality, and habitat construction are better understood. World-wide studies have generated a growing database of production rates (e.g. Patriquin, 1972; Zieman et al., 1989; Gallegos et al., 1994; van Tussenbroek, 1995), resource acquisition strategies (e.g. Patriquin, 1972; Larkum and James, 1996; Stapel et al., 1996), reproductive strategies (e.g. Lewis and Phillips, 1980; Johnson and Williams, 1982; Cox and Tomlinson, 1988; Witz and Dawes, 1995) population structures (e.g. Duarte et al., 1994; and Gallegos et al., 1994; Cutler and Childers, 1998); disturbances (for review see Short and Wyllie-Echeverria, 1996) and interspecific relationships (e.g. Williams, 1987; Fourqurean et al., 1995; Holmquist, 1997), as well as many other physiological and population-level processes of seagrass ecosystems. System function and stability, rather than structure, are often considered more valuable to our understanding of an ecosystem, because the processes occurring dictate the component structures 
and relationships (McRoy and Lloyd, 1981). However, a gap exists in our knowledge of tropical seagrass ecosystems concerning the interspecific relationships between the dominant seagrasses and coexisting rhizophytic, green macroalgae of the order Caulerpales. Though mentioned often in tropical seagrass literature (den Hartog, 1971; Patriquin, 1975; McRoy and Lloyd, 1981; Zieman, 1982; Multer, 1988; Williams, 1985, 1988), attempts at field experimentation or observational analysis concerning possible interactions between these species are limited (Williams, 1990). In order to enhance models of seagrass ecosystem dynamics for future management prospects (see Fong and Harwell, 1994), interspecific relationships should be investigated, as these macrophytes are among the system's prevalent components. According to Gopal and Goel (1993), little effort has been devoted to the study of interspecific interactions and their role in regulating the organization of aquatic plant communities. McRoy and Lloyd (1981) further claim that the best understanding of a macrophyte-based ecosystem comes from a comparison of those processes leading to its development and maintenance at a certain level of maturity. This study integrates important interspecific relationships in both settings: within a mature seagrass community and over a successional gradient. 


\section{Dominant Macrophytes in Tropical Atlantic Seagrass Meadows}

Neotropical seagrass meadows consist of a very limited number of seagrass species. By far the most abundant is Thalassia testudinum Banks ex König. Syringodium filiforme Kützing is the next most common, sometimes forming monospecific beds but most often co-occurring in mixed communities. Halodule wrightii Aschers is the least common of the three species considered in this study, and although its distribution is more limited, it may form dense beds as well. The algae considered in this study are of the order Caulerpales, division Chlorophyta. Many of these green macroalgae are rhizophytic, and are thus capable of colonizing the shifting sediments necessary for the development of seagrass meadows. The most common representatives of this group, and therefore the species considered within this study, are Halimeda incrassata Lamouroux, Halimeda monile Lamouroux, Penicillus capitatus Lamarck, Penicillus dumetosus Blainville, Penicillus pyriformis Gepp, Rhipocephalus phoenix Kuetzing, and Udotea flabellum Lamouroux. 


\section{Morphologies, Life Histories and Resource Acquisition Strategies}

The dominant seagrasses and rhizophytic macroalgae have significantly different morphologies, life histories, and resource acquisition strategies that influence their relative roles in the development and maintenance of their communities. These differences can lead to potential trade-offs in colonization ability, longevity, and competitive ability (Tilman, 1994). Identifying these trade-offs may help to generate hypotheses concerning possible interspecific interactions.

\section{Morphologies}

Seagrasses expand via horizontal rhizomes, producing root bundles and lateral buds at regular intervals. These buds become vertical short-shoots with foliage leaves that usually reach heights of $10-25 \mathrm{~cm}$. Rhizomes are usually buried $5-25 \mathrm{~cm}$ in the sediment. Horizontal rhizome expansion, or vegetative reproduction, occurs via apical meristems (Tomlinson and Vargo, 1966). The relative investment in belowground biomass is highest in Thalassia testudinum, intermediate in Syringodium filiforme and Halodule wrightii, and lowest in rhizophytic macroalgae (Williams, 1990). 
The rhizophytic macroalgae anchor themselves in the sediment with a

rhizoid bulb. Interwoven, coenocytic filaments make up an erect thallus which is photosynthetic to varying degrees and supports a photosynthetic frond. Most of these algae secrete a calcareous exoskeleton through calcification, which may comprise $20-90 \%$ of its total dry weight (Bach, 1979). Calcification may have several advantages. Those most commonly listed are structural support, defense against herbivory, and the reduction of epiphytic cover due to carbonate sloughing (Hillis-Collinvaux, 1980).

\section{Life Histories}

Seagrasses shoots, or ramets, can be aged by counting leaf scars, each of which represents the passing of one plastochrone interval (Duarte et al., 1994). Using this technique, the average life expectancy of shoots of Thalassia testudinum, Syringodium filiforme, and Halodule wrightii have been estimated (see Table 1). According to Gallegos et. al. (1994), reproductive effort and rhizome turnover are highest for $H$. wrightii, intermediate for S. filiforme, and lowest for T. testudinum, which corresponds to the successional sequence of these species described in the literature (den Hartog, 1971; Zieman, 1982). 
Although vegetative reproduction is more common, all seagrasses utilize sexual reproduction to some degree. The three seagrass species of this study are all included in the small group (3-4\%) of flowering plants that are dioecious (Moffler and Durako, 1987). Thalassia testudinum has a low flowering frequency (Durako and Moffler, 1985; Witz and Dawes, 1995) that generally has a variable interval (Cox and Tomlinson, 1988), though it has been found in fairly regular intervals (van Tussenbroek, 1995), and has been correlated to changes in salinity and temperature (Phillips et al., 1981; Durako and Moffler, 1987). Inflorescences commonly develop from April to September, with a peak in June (Durako and Moffler, 1987; van Tussenbroek, 1995). Male plants release spherical pollen grains in mucilaginous strings. The strings are negatively buoyant and drift horizontally along the substrata until they encounter female flowers (Cox and Tomlinson, 1988). Fruits are found typically in late summer (Zieman, 1975). Seed capsules which are positively buoyant are released before maturity, and may be carried long distances before splitting to release one to six seeds (Witz and Dawes, 1995). Seed crops apparently vary from year to year (Lewis and Phillips, 1980), and seedling success is suspected to be low (Zieman, 1975; Williams and Adey, 1983). 


\begin{tabular}{|cccc|}
\hline & $\begin{array}{c}\text { Thalassia } \\
\text { testudinum }\end{array}$ & $\begin{array}{c}\text { Syringodium } \\
\text { filiforme }\end{array}$ & $\begin{array}{c}\text { Halodule } \\
\text { wrightii }\end{array}$ \\
\hline $\begin{array}{c}\text { Life expectancy } \\
\text { (years) }\end{array}$ & 1.5 & 0.5 & 3 months \\
\hline $\begin{array}{c}\text { Leaf production } \\
\left(\mathrm{gdw}(\mathrm{gdw})^{-1} \mathrm{~d}^{-1}\right)\end{array}$ & 0.022 & 0.052 & 0.072 \\
\hline $\begin{array}{c}\text { Rhizome expansion } \\
(\mathrm{cm} / \mathrm{yr})\end{array}$ & $20-45$ & 51.6 & 80.9 \\
\hline $\begin{array}{c}\text { Below : } \\
\text { Aboveground } \\
\text { Investment }\end{array}$ & $60: 1$ & $11: 1$ & $10: 1$ \\
\hline
\end{tabular}

\section{Table 1}

(data from Zieman et al., 1989b; Williams, 1990; Gallegos et al., 1993;

Gallegos et al., 1994; and present study) 
The density of flowering for Halodule wrightii and Syringodium

filiforme shoots is $10-50$ fold greater than that of Thalassia testudinum (Gallegos et al., 1994). Few quantitative analyses of sexual reproduction in these species exist (Moffler and Durako, 1987), however Johnson and Williams (1982) found that the reproductive activity of $S$. filiforme was greater than vegetative meristematic activity for part of the year. Peak reproductive densities occurred in late April with seed maturation in early May, which closely paralleled flowering and seed maturation for Halodule wrightii. Flowering shoots of $H$. wrightii have been found to be five times as dense as those of $S$. filiforme (Gallegos et al., 1994). Seeds may remain dormant in these species for several years (Moffler and Durako, 1987). Probably the most important difference for $H$. wrightii is that its fruits develop at the rhizome level and may remain buried for long periods of time, thus creating a viable seed bank. A seed bank permits rapid recolonization following a disturbance, however this strategy limits dispersal potential relative to those fruits which mature above the sediment (Moffler and Durako, 1987).

The rhizophytic macroalgae have higher growth rates than the seagrasses (Littler, 1980; Multer, 1988), as well as significantly higher turnover rates (Hillis-Collinvaux, 1980) and shorter life spans (Bach, 1979). 
They are often considered the most efficient colonizers in these macrophyte communities (Williams, 1990). Bach (1979) reported life spans of 40-96 days, 25-75 days, and 75-99 days for Penicillus capitatus, Rhipocephalus phoenix, and Udotea flabellum, respectively. Halimeda incrassata has slightly slower growth and dispersal, with a corresponding longer life span on the order of eight months (Hillis-Collinvaux, 1980).

The relative roles of vegetative and sexual reproduction for Caulerpalean algae are not well understood (Clifton, 1997). Because sexual reproduction results in a zygote that appears to enter into a resting phase that may last for many months before development into an active thallus (HillisCollinvaux, 1980), clonal reproduction may be most important for these species. The macroalgae may reproduce vegetatively by fragmentation or budding, but commonly propagate via creeping rhizoids within the sediment stemming from the anchoring rhizoid bulb. Following a grazing disturbance, Bach (1979) found a large area completely recolonized by Halimeda incrassata, solely by regeneration from buried rhizoid bulbs. In a study by Hillis-Collinvaux (1980), Penicillus capitatus, Rhipocephalus phoenix, and Udotea flabellum had nearly doubled their densities via vegetative propagation in a lab culture after five weeks, and $H$. incrassata increased its density by $70 \%$ after sixteen weeks. 
Caulerpalean algae are also dioecious. Sexual reproduction occurs

during a 36-hour event (Clifton, 1997). For various species, about 3-20\% of populations, (sometimes thousands of thalli), become simultaneously fertile overnight, with gametes migrating into the external gametangia. Before dawn, the algae release their entire protoplasmic content, leaving the parent thallus dead and white in appearance. Green clouds or streams of anisogamous gametes reduce water clarity above the meadow for several minutes. The gametes remain motile for up to an hour after release, and can cover distances of up to one meter within a matter of minutes. Based on these findings, the maximum range for dispersal of a zygote would appear to be on the order of 30-60 m from the site of gamete release. Upon fusion with another gamete, the resultant zygote is negatively buoyant and quickly sinks. The parent thallus is usually completely disintegrated in a matter of hours, meaning that the entire sexual event, from onset to disintegration of the parent, can take as little as 36 hours (Clifton, 1997).

\section{Resource Acquisition Strategies}

Thalassia testudinum has lower nutrient requirements than other neotropical seagrasses (Fourqurean et al., 1992a) because of its slow growth and longer life span. It also has a higher degree of nutrient retention, because 
its abscised leaves sink and often decompose locally (Gallegos et al., 1994,

Stapel et al., 1996). Resource requirements likely increase from Syringodium filiforme to Halodule wrightii, which has the highest growth rate of the three species (see Table 1).

Patriquin (1972) found that a significant portion of phosphorus and virtually all nitrogen for Thalassia testudinum leaf growth was taken up from the sediment. Williams (1990) reviews several studies which build evidence suggesting that $T$. testudinum development is largely limited by sediment nutrient availability. However, some studies have shown that the relative role of leaf versus root uptake of nutrients in seagrasses is not completely understood, and may vary with the presence of alternate sources. Furthermore, nutrients may be taken up by seagrass leaves as they diffuse out of the sediments, which could impede detection of sediment vs. water column sources (for review see Hemminga et al., 1991). Stapel et al. (1996) found that the availability of nitrogen and phosphorus in the root and leaf zone affected the uptake affinity of the leaves of Thalassia hemprichii, and that leaf uptake may be essential for growth even in oligotrophic waters.

Most marine algae take up nutrients entirely from the water column since they have no root-like structures within the sediment. Rather they utilize small holdfasts to attach to hard substrates or drift freely. However, 
Williams (1984) found that Halimeda incrassata, Halimeda monile, and Penicillus capitatus were capable of the translocation of porewater nutrients from rhizoids into the thallus. She further claimed that sediments appeared to be the most important source of these nutrients.

\section{Possible Species Interactions}

The potential interspecific interactions among rooted plants include consumptive, preemptive, overgrowth or chemical competition (Schoener, 1983); obligate or facultative mutualism (e.g. Quispel, 1974); facilitation (e.g. Turner, 1983); and resource partitionment (Williams, 1990). Consumptive competition may occur when one species better utilizes a limiting resource necessary for the survival of another. Preemptive competition is competition for available space. Overgrowth competition usually results in decreased light availability for the lessor competitor, while chemical competition is a direct negative impact of one species on another by the release of harmful chemicals. Conversely, the benefits from a mutualistic or facilitative interaction may include enhanced colonization, growth, predator avoidance, or reproduction. The case of resource partitionment refers to the potential for coexisting species to utilize different resource 
acquisition strategies even when limited by the same nutrient. These interactions may not be mutually exclusive. For example, one species may facilitate the colonization of a better competitor or the presence of a species may enhance the resource acquisition of its competitor.

\section{A Spatial Competition Hypothesis}

According to Tilman (1994), community diversity requires limited similarity and trade-offs in colonization ability, competition, and longevity of the individual species that compose the community. Studies of sessile organisms suggest that, despite strong neighborhood interactions (those interactions between an organism and its immediate neighbors), different community compositions may persist due to the dispersal limitations of superior competitors. Because greater investment in roots and rhizomes is at the expense of reproductive investment, these superior competitors often have increased longevity and slower dispersal. This led Tilman to question whether superior competitors are only prevented from occupying an entire landscape because of dispersal or colonization limitation, thus providing sites for inferior competitors with greater dispersal capabilities. Plants with limited similarity could coexist even while competing for a single limiting resource if 
their higher dispersal rates allowed them to persist in sites not occupied by superior competitors. The theory is based on neighborhood competition, random dispersal between neighborhoods, and spatial subdivision. It does not require large-scale disturbances, but rather it assumes a spatially homogenous habitat.

Seagrasses and macroalgae that coexist in seagrass communities are well suited to test the spatial competition hypothesis. The limited similarity condition is met, based on the previously defined physiological and reproductive differences between seagrasses and algae. A trade-off does exist in seagrass longevity at the expense of greater colonization ability. Finally, the homogenous physical environment assumption may be closely approximated in an aquatic setting. If neighborhood competition between seagrasses and macroalgae can be demonstrated, then the widespread coexistence of these macrophytes may be explained by Tilman's spatial competition hypothesis. 


\section{A Two Part Study}

Inferences concerning interspecific associations are often drawn from observations of spatial patterns. Rejmánek and Leps (1996) suggested that the most powerful method for determining interspecific interactions between plant communities involves repeated observations in time supplemented by experimental manipulations. The following chapters present a two-part investigation of interspecific interactions between the seagrasses and algae: one observational and one experimental. The goal of this study is to evaluate possible interspecific interactions that may be structuring neotropical seagrass communities from the spatial distributions of the dominant macrophytes (Chapter 2), and to further test these inferences experimentally (Chapter 3).

\section{Part I : Observational Data}

\section{Large-Scale Spatial Analysis}

The first objective of this study was to document the spatial distributions of the dominant macrophytes over large and small spatial scales. I have chosen a subarea of the Florida Keys National Marine Sanctuary defined as Segment IX, Upper Keys Ocean-side. The subareas were based 
on classifications of the dominant water transport influences for sections of the sanctuary, and the 1,011 square kilometers occupied by Segment IX are defined as an area confined by the reef tract that is dominated by the Florida current frontal eddies, with 478 square kilometers of seagrass communities (Klein and Orlando, 1994).

Following the presentation of spatial distribution data, correlations between the abundances and densities of the dominant macrophytes will be presented. Evidence for interspecific interactions will be inferred from positive or negative correlations between the spatial distributions of seagrass and macroalgal abundances.

\section{Small-Scale Spatial Analysis}

Studies of ecological succession often reveal interspecific interactions present during community development (Schoener, 1983). For example, species zonation in intertidal communities has been shown to be strongly influenced by interspecific interactions rather than solely by abiotic influences (review in McRoy and Lloyd, 1981). I studied a secondary succession sequence that exists in tropical seagrass meadows dominated by Thalassia testudinum (Figure 1). The species sequence seems to agree with many of Odum's (1969) table of successional trends: increasing complexity of food 
webs (Zieman, 1975), resistance to disturbance (Thomas et al., 1961), total organic matter (Zieman et al., 1989), size of organisms, and longevity (Gallegos et al., 1994); and decreasing growth and reproductive rates (Gallegos et al., 1994).

Zieman (1982) also described a particular seagrass recolonization event following a "blowout"; or, an erosional disturbance patch that migrates slowly and directionally across a seagrass meadow (Figure 2). A blowout is initiated by some form of bottom disturbance, commonly storm waves or human-induced damage, which is enlarged by water flow that continually erodes the up-current edge or scarp (Patriquin, 1975). A crescent-shaped patch commonly results, migrating from 20 to $150 \mathrm{~cm} / \mathrm{yr}$ with a relief of about one meter (Patriquin, 1975; Wanless, 1981). Crescent blowouts are common on banks exposed to high impact from storm waves, on 1 to $3 \mathrm{~m}$ deep platforms exposed to offshore waves, and in 3 to $6 \mathrm{~m}$ depths behind reef barriers, and occur only in sandy substrates (Patriquin, 1975; Wanless, 1981). In the highly disturbed center of the patch, rubble, constant turbulence, and/or herbivory pressure may prevent seagrass or algal colonization. With increasing distance from the erosional edge, the successional stages of recolonization may become established. 


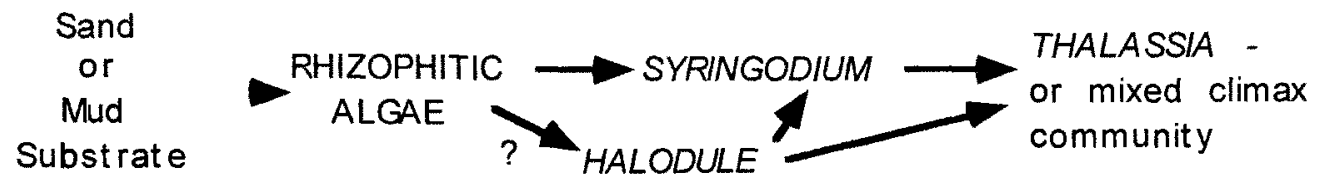

\section{Ecosystem Development}

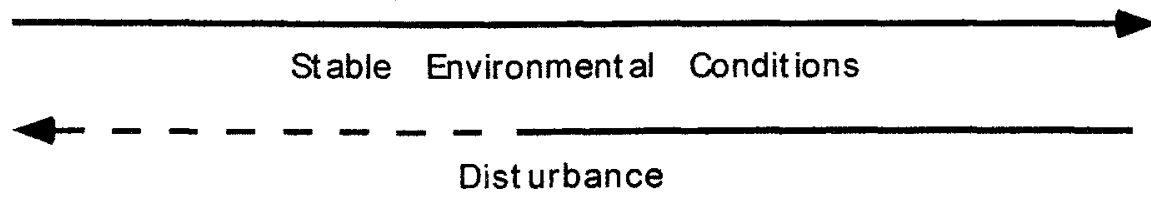

Figure 1. Hypothetical seagrass community recolonization sequence based on initial substrate, (adapted from Williams, 1990).

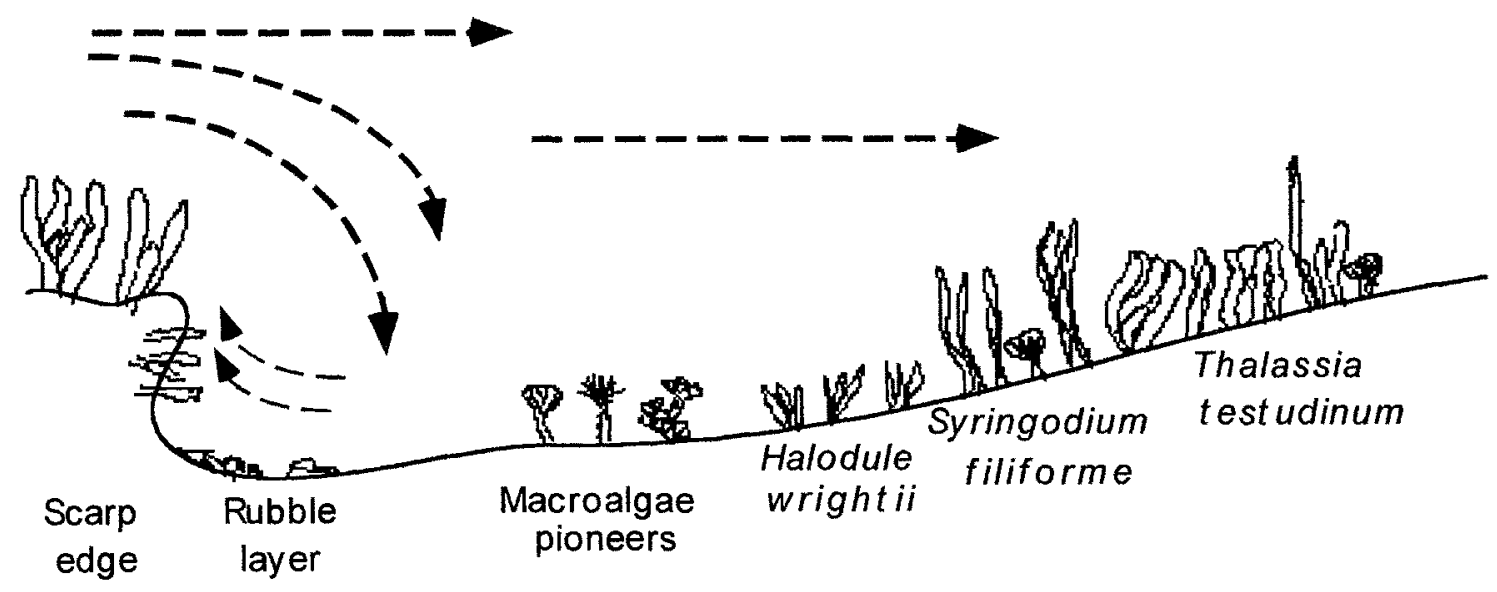

\section{Prevailing Current}

\section{Blowout Migration}

Figure 2. Cross-section of idealized blowout, abiotic processes and species zonation, taken from Zieman (1982). 
For this zonation of species to be entirely controlled by environmental factors, abiotic forces would have to change the climax community for each zone. The alternative hypothesis is that differences in dispersal abilities or interspecific interactions create distinct species zonations. Williams (1987) suggested that the decline of Syringodium filiforme densities as Thalassia testudinum becomes abundant over the course of successional development is evidence of competition between these species, and verified this hypothesis with an experimental study. Fourqurean et al. (1995) investigated competition as the interaction responsible for the displacement of Halodule wrightii by Thalassia testudinum during secondary succession, and again the competition hypothesis was verified by experimental manipulation. During the recolonization of experimental disturbance plots, Williams (1990) observed an initial increase in macroalgal densities followed by a decline as T. testudinum densities linearly increased. An experimental test for competition between these species is carried out in the second part of this study.

Blowouts present naturally occurring disturbances around which any spatial patterns of the dominant macrophyte species can be observed. In Part I of this study, field surveys describe the species distributions around these smaller-scale, migrating disturbances. The spatial distribution is 
assumed to represent a chronosequence of the development of the seagrass

beds. Apparent species turnover events within this chronosequence may implicate interactive mechanisms as structuring forces of the seagrass communities.

\section{Part II : Field Experiment}

To further test inferences from spatial distributions in Part I, an experiment was conducted to test for positive or negative interactions between Thalassia testudinum, the dominant seagrass species, and Halimeda incrassata, a representative of the Caulerpalean algae. H. incrassata is the most common representative of the Caulerpalean algae within the study area. Despite differences in longevity, growth and calcification between $H$. incrassata and other rhizophytic algae, it is representative of the significant differences compared to seagrasses in life history strategies and physiologies. Four treatments were compared over a four-month period: Algal Removal, Algal Addition (double-density), Seagrass Removal, and Control. Seagrass additions were not attempted due to difficulties in transplanting. Interactions are inferred from measurements of short-term productivities and biomass. Nitrogen and substrate-level irradiance were examined as possible underlying mechanisms of the interaction. 
Chapter Two

\title{
Macrophyte distribution within the Florida Keys National Marine Sanctuary: Determining large and small-scale spatial patterns.
}

\begin{abstract}
Spatial abundance patterns were investigated to reveal trends in the distribution and successional sequence of the dominant seagrasses and rhizophytic macroalgae over large and small spatial scales in the Florida Keys National Marine Sanctuary. A significant negative correlation exists between abundances of the dominant seagrass, Thalassia testudinum and rhizophytic algal abundances over a regional scale. Field surveys of seven blowout disturbances demonstrated weak and inconsistent species zonations around migrating sand patches. No significant decreases in density were detected for macroalgae or seagrasses as a function of distance from disturbances, therefore no successional species turnover events were evident within the study area.
\end{abstract}


Extensive benthic surveys of tropical seagrass meadows have demonstrated the widespread coexistence of seagrasses and rhizophytic green macroalgae of the order Caulerpales. This study considers whether or not spatial patterns exist in species abundances as a result of proposed interspecific interactions. These spatial patterns could help define trends in the distribution and succession of the dominant macrophytes of tropical seagrass meadows, which could enhance ecosystem models for these communities (see Fong and Harwell, 1994).

Three seagrass species dominate the coastal benthic communities of South Florida: Thalassia testudinum Banks ex König, Syringodium filiforme Kützing, and Halodule wrightii Aschers. The three seagrass species differ slightly in morphology. T. testudinum has wide leaves and a greater investment in below-ground biomass. S. filiforme has narrow, tubular leaves, and $H$. wrightii has smaller, narrow leaves and less investment in belowground roots and rhizomes. T. testudinum is often considered the dominant species of the climax successional community, having relatively slow growth, greater longevity (Gallegos et al., 1993) and low reproductive output (review in Moffler and Durako, 1987). As a result, the species accordingly has lower nutrient requirements (Fourqurean et al., 1992). S. filiforme often coexists 
with and is considered intermediate between $T$. testudinum and $H$. wrightii in growth, reproductive output and longevity (Gallegos et al., 1994).

The dominant coexisting macroalgae, of the order Caulerpales, have distinct physiologies and life history strategies which should be considered before discussing spatial distribution patterns. The most abundant macroalgal species are the rhizophytic green algae of the order Caulerpales. Able to anchor in the sediment with rhizoid bulbs, these algae usually have an erect thallus supporting a photosynthetic frond, which ranges in morphology from many bristles to jointed segments. Despite roughly equivalent production rates compared with seagrasses (Chapter 3), the macroalgal species are considered pioneers of the successional sequence (Zieman, 1982), with rapid turnover rates (Wefer, 1980; Freile and Hillis, 1997), shorter longevities (Bach, 1979), and greater investments in reproduction (Clifton, 1997).

\section{Large-Scale Abundance Distributions}

Previous studies have demonstrated interspecific competition between Thalassia testudinum and Syringodium filiforme (Williams, 1987); and between T. testudinum and Halodule wrightii (Fourqurean et al., 1995). A study by Williams (1990) showed a decrease in rhizophytic macroalgae as seagrass densities increased in experimental disturbance plots. Chapter 3 
presents further evidence of competition between a representative of the rhizophytic macroalgae, Halimeda incrassata, and T. testudinum. I hypothesized that these interspecific interactions among the common macrophytes should result in negative correlations between species densities, creating large- and small-scale spatial patterns of relative abundances.

\section{Small-Scale Density Patterns}

I studied a secondary succession sequence in tropical seagrass meadows dominated by Thalassia testudinum (Figure 3); (den Hartog, 1970; Zieman, 1982; and Williams, 1990). Patriquin (1975) described a particular seagrass recolonization event following a "blowout"; or, an erosional disturbance patch that migrates slowly and directionally across a seagrass meadow, into the prevaling current (Figure 4). Because these disturbances migrate, the distance to a point downstream from the erosional scarp is related to the amount of time that has passed since the disturbance affected that point. By using distance as a surrogate for time, one can quantify macrophyte recolonization over the course of succession. However, this involves two basic assumptions. First, inherent in the use of chronosequences for successional study is the assumption that each point in space developed under equivalent conditions. Second, each blowout is assumed to have 
migrated at least $25 \mathrm{~m}$, or the maximum transect distance studied.

Macrophyte recolonization along the trailing edges of blowouts has been described in the literature (Patriquin, 1975; Zieman, 1982; Kirkman, 1985), but has yet to be quantified. Species recolonization is hypothesized to follow the models presented in Figures 5 and 6. Species turnover events should result in negative correlations between the relative densities of the seagrasses and rhizophytic macroalgae. 
Sand

\section{Ecosystem Development}

$\longrightarrow$ Stable Environmental Conditions

Figure 3. Idealized model of tropical seagrass community development, (adapted from Williams, 1990)

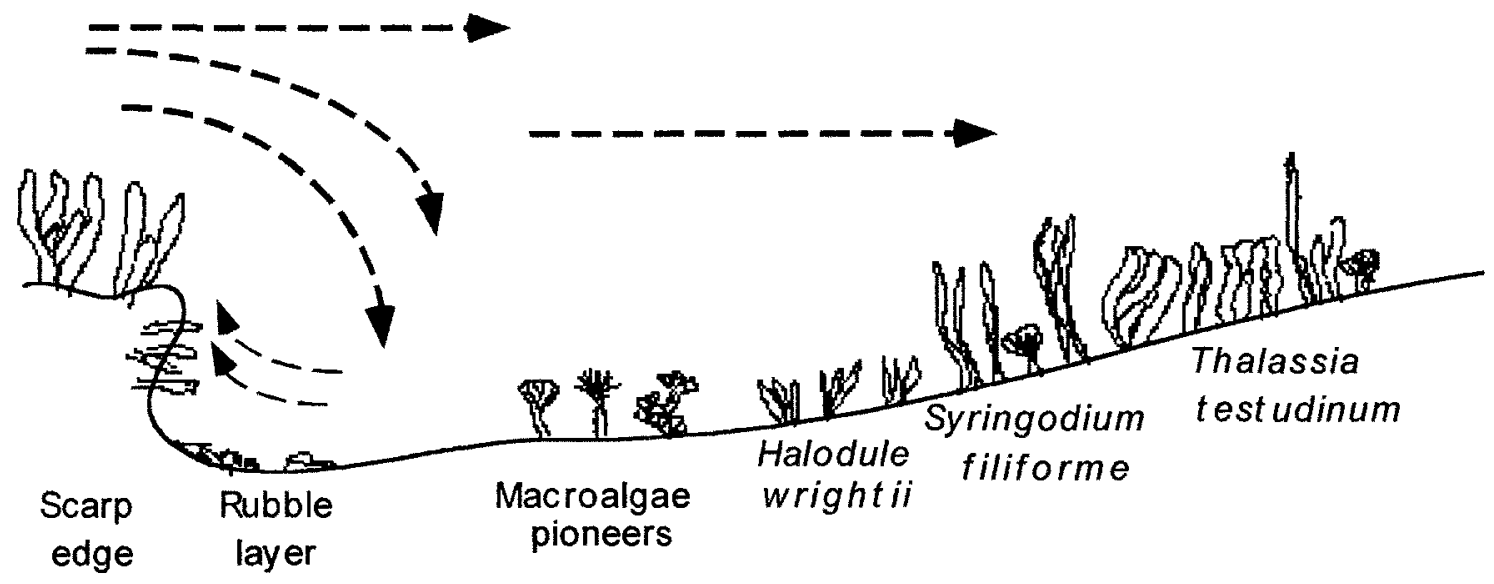

\section{Prevailing Current}

\section{Blowout Migration}

Figure 4. Cross-section of hypothetical blowout disturbance and recovery species zonation, (adapted from Zieman, 1982). 


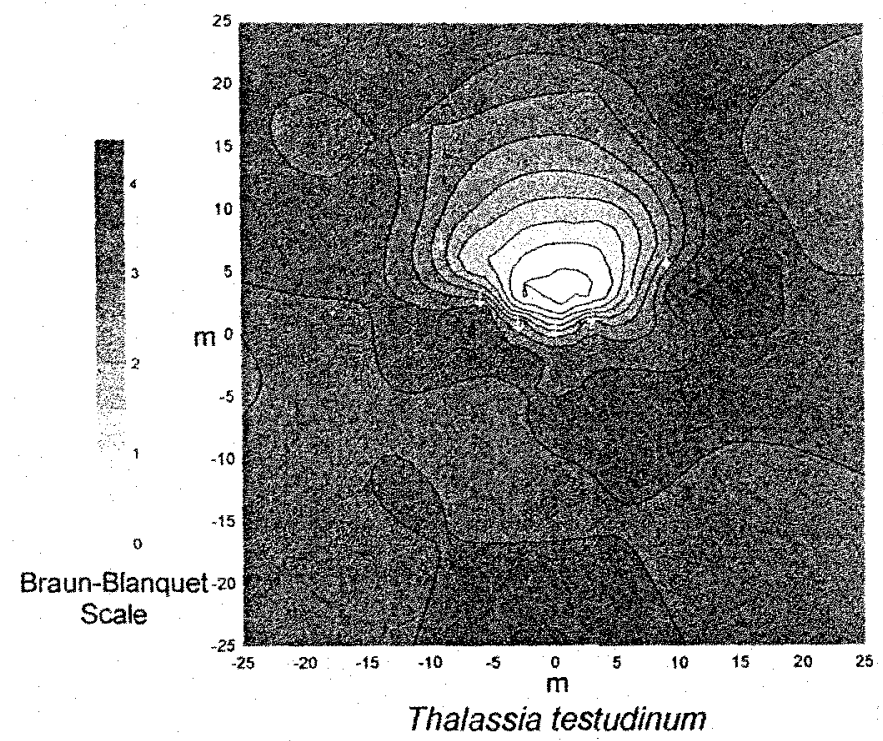

N

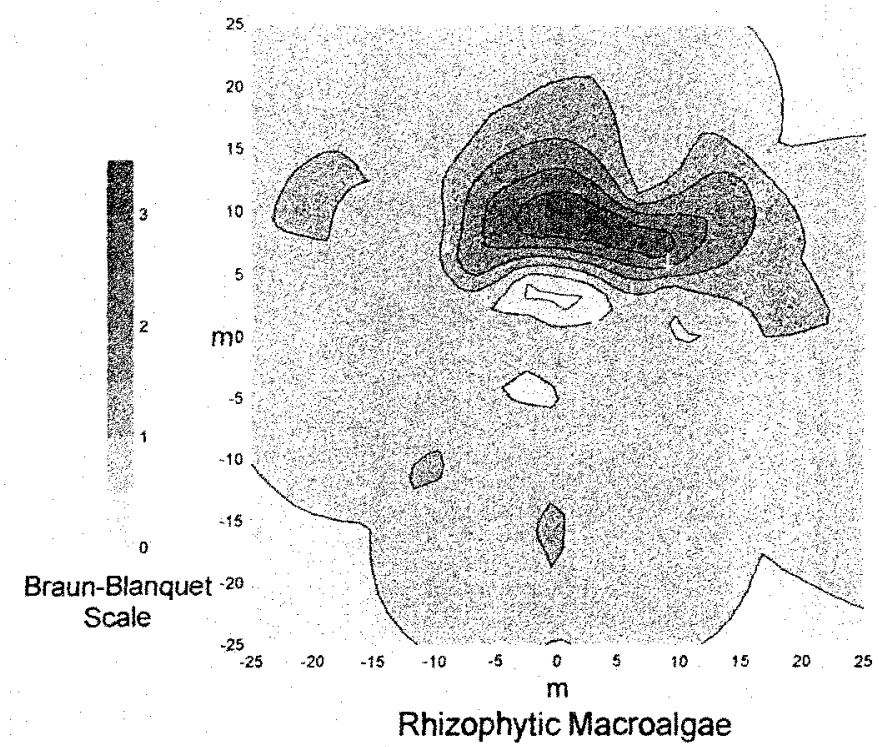

Figure 5. Hypothetical model of species zonation patterns

\section{Fround migrating blowout disturbances.}

Braun-Blanquet -20 Scale

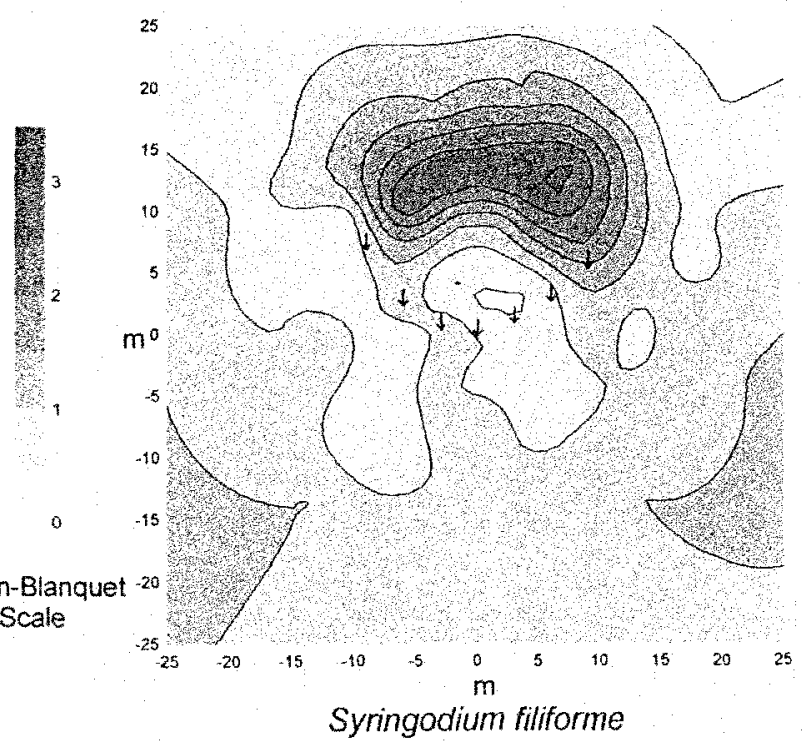




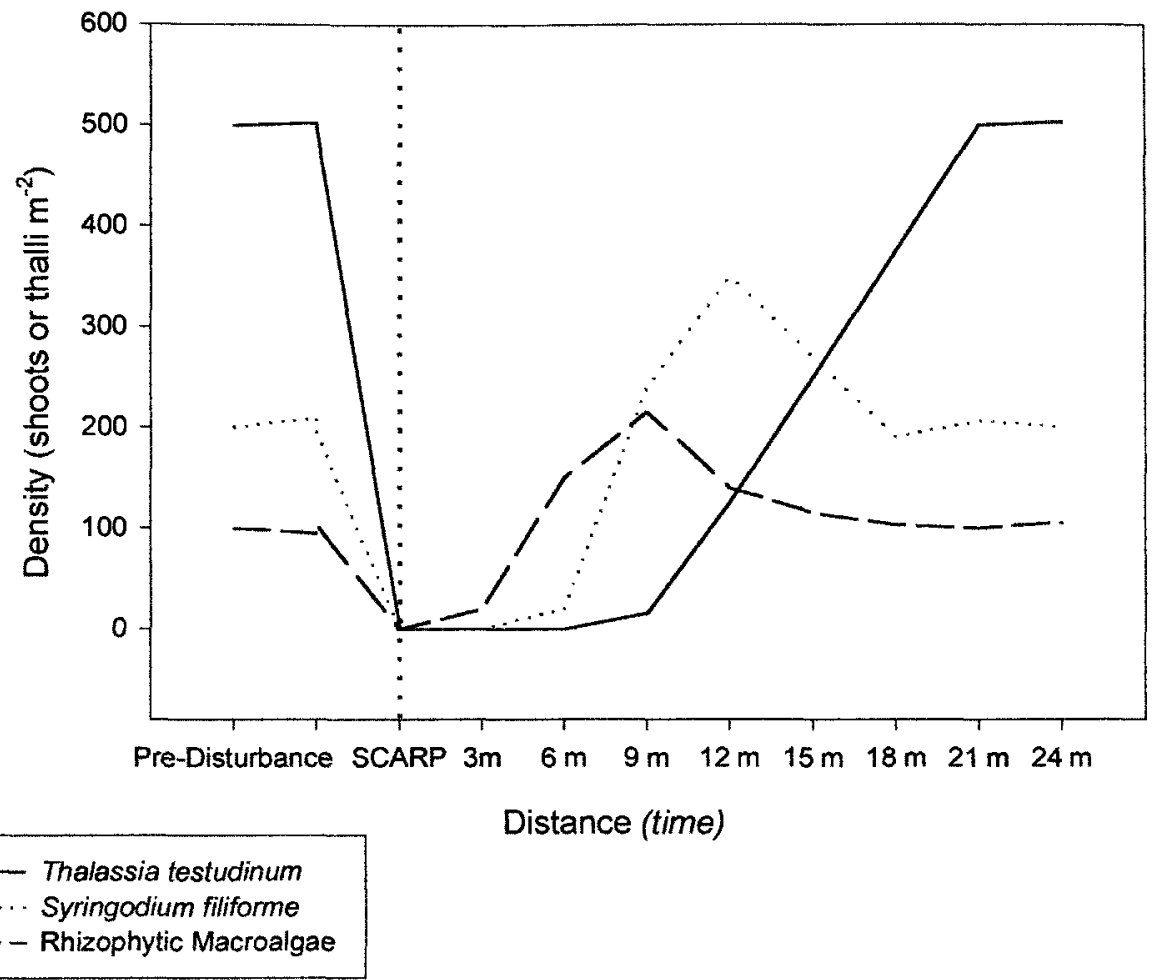

Figure 6. Predicted sequence of macrophyte recolonization densities based on current models and experimental manipulations (Zieman, 1982; Williams, 1990). 
Study Area

I chose a subarea of the Florida Keys National Marine Sanctuary defined as Segment IX, Upper Keys Ocean-side. The subareas are based on the dominant water transport influences for various sections of the sanctuary. The 1,011 square kilometers occupied by Segment IX are defined as an area confined by the reef tract and dominated by the Florida current frontal eddies, with 478 square kilometers of seagrass communities (Klein and Orlando, 1994).

As part of the seagrass monitoring program for the Sanctuary (EPA, 1995), the status and trends of seagrass communities have been the subject of intense study over the past three years. The large-scale spatial abundance data for this study came from 29 randomly selected sites within segment IX, which were surveyed during the summer of 1996 (Figure 7). Site locations were selected using the USEPA/EMAP protocol of hexagonal tesselation which provided a quasi-even distribution of randomly selected points. Blowout disturbances studied for small-scale spatial patterns were also within Segment IX (Figure 8). 


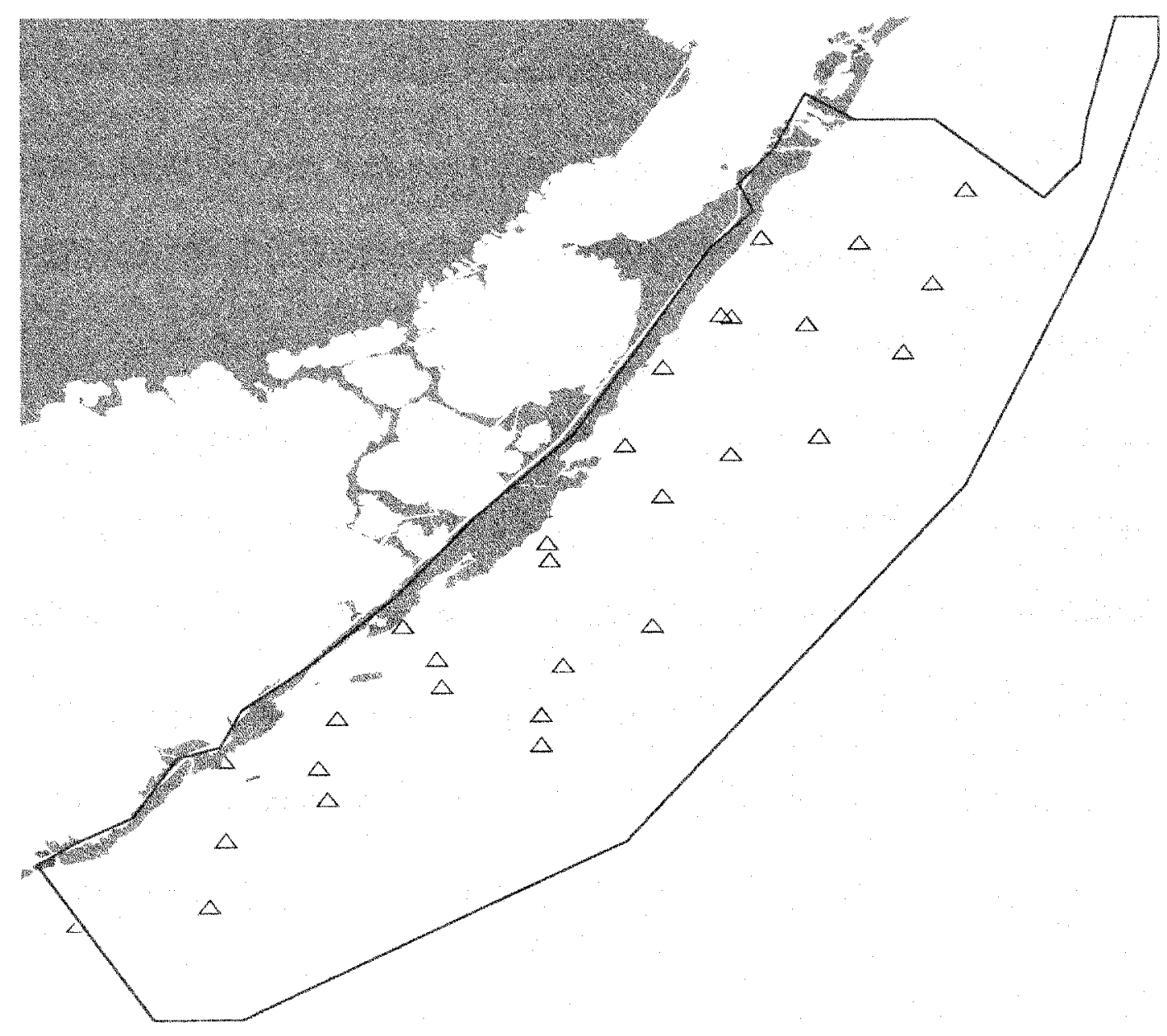

Figure 7. Sampling stations used for large-scale spatial analysis within Segment 9. 


\section{Large-Scale Spatial Analysis}

At each random location, a $50 \mathrm{~m}$ transect was laid out due north from the boat anchor. Within ten randomly placed $0.25 \mathrm{~m}^{2}$ quadrats along the transect, the density of each macrophyte genus, as well as the total calcareous green algal density, was estimated using the Braun-Blanquet method (BraunBlanquet, 1972). A value was assigned for each genus based on a percentcover estimate for each quadrat as follows: $0.1=$ solitary; $0.5=$ few; $1=$ numerous, less than $5 \%$ cover; $2=5-25 \% ; 3=25-50 \% ; 4=50-75 \%$; and 5 $=75-100 \%$ cover. Abundance was calculated as the sum of Braun-Blanquet scores divided by the number of quadrats in which the genus was found. To test for large-scale spatial trends, a Spearman Rank Order Correlation Analysis was performed for abundances of Thalassia testudinum, Syringodium filiforme, and calcareous green macroalgae.

\section{Small-Scale Spatial Analysis}

Blowout disturbances were chosen based on length (between 20 and 40 meters) and shape. An underlying assumption in this study is that each disturbance has migrated across the seagrass bed. I assumed that a disturbance which had obtained a near-perfect crescent shape from prevailing 
hydrological conditions was older and potentially had a more consistent migration route than a disturbance with irregular features.

A baseline transect was first laid along the horizontal axis of the crescent; perpendicular to the prevailing current, and $50 \mathrm{~cm}$ from the edge of the erosional scarp at its widest point. Next, from a stake placed at the midpoint of the baseline, ten transects were laid out downstream of the scarp at 20 degree angle increments, until meeting the baseline on the opposite end of the crescent (see Figure 9). Five $0.25 \mathrm{~m}^{2}$ quadrats were placed in a stratified random design along each transect, one within each $5 \mathrm{~m}$ interval up to $25 \mathrm{~m}$, where seagrass percent-cover (using the Braun-Blanquet scale) and rhizophytic green macroalgal densities were recorded. 


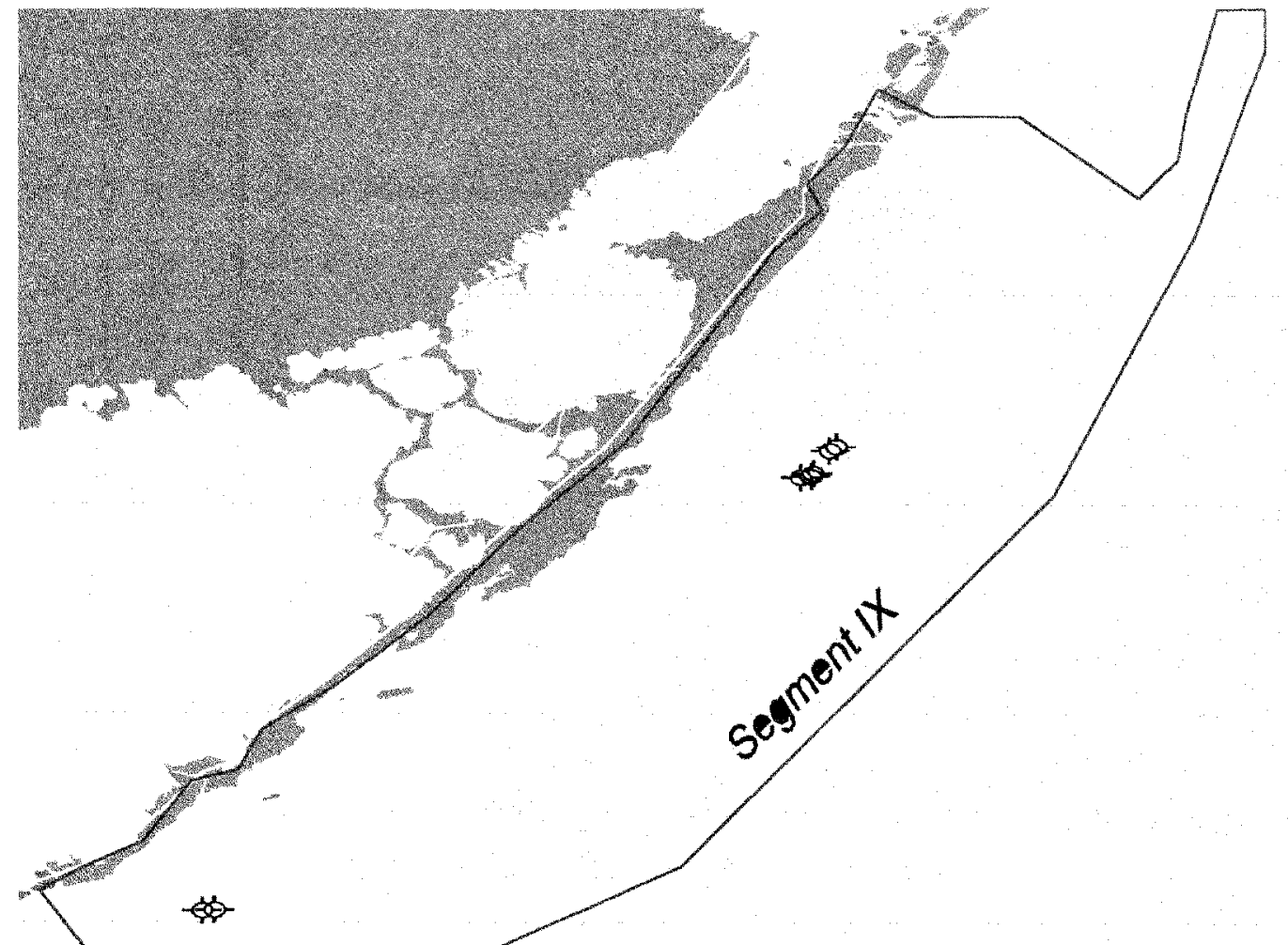

Figure 8. Blowouts survey locations, (used for small-scale distribution analyses). 


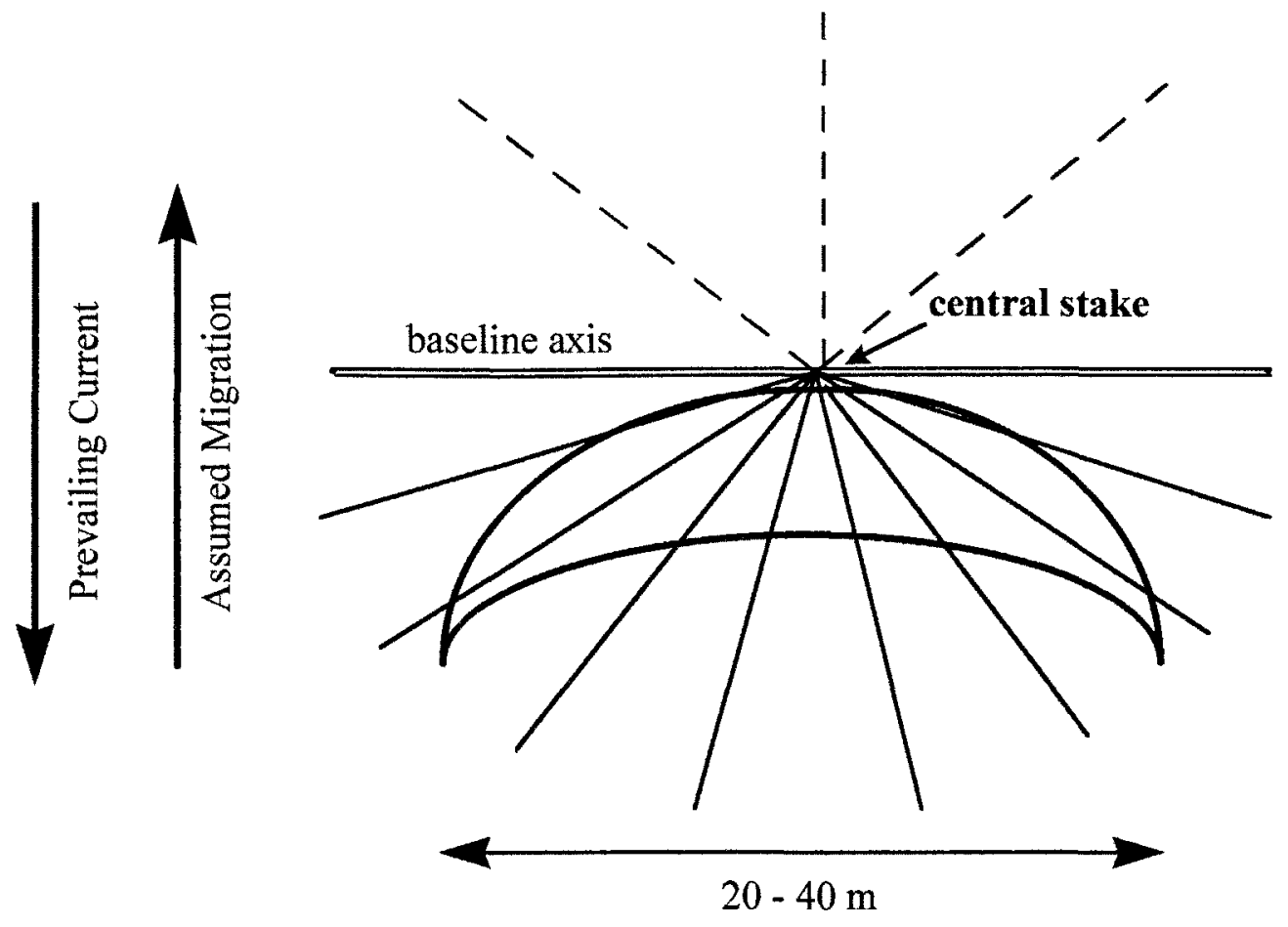

Figure 9. Positioning of transects around the crescent-shaped disturbances, dashed lines represent added transects.

After surveying four blowouts, I decided to increase the magnitude of the sampling effort by adding three transects across the seagrass bed in the apparent path of the migrating blowout, hoping to yield a "before and after" image of species abundances and distributions. Two transects were sampled at 45 degrees and one at a 90 degree angle to the horizontal axis of the blowout. The increased sampling was performed only in three additional blowout surveys (Figure 9). 
The data were analyzed in three parts. First, contour maps were generated that provided an overview of species distributions around each blowout. The maps were generated using the Krigging method of data interpolation (Watson, 1992). These may be compared with Figure 5, a contour map model based on the predicted recolonization sequence (Zieman, 1982; Williams, 1990). The maps may also be used to generate hypotheses concerning species distributions around each disturbance. Next, recolonization was expected to follow the graphical model presented in Figure 6. In the recolonization area following the assumed path of each blowout, density values for each species were binned according to the distance of each quadrat from the erosional scarp (or time since disturbance), in the following distance classifications: $0-3,3-6,6-9,9-12,12-15,15-18,18-$ 21 , and 21-25 m. Decreasing densities with increasing distance from the disturbance would imply a species turnover event. Third, a Spearman Rank Order Correlation Analysis generated a species density correlation matrix based on per quadrat densities from all areas of all disturbances studied. Species turnover events should result in negative density correlations between species, assuming that $25 \mathrm{~m}$ is an adequate spatial scale in which to find such an event. 


\section{RESULTS}

\section{Large-Scale Spatial Analysis}

Halodule wrightii was not present at any of the sampling stations.

Highest abundances of Thalassia testudinum are generally found within the deeper Hawk Channel, between the nearshore and reef environments (Figure 10). Syringodium filiforme abundances apparently increase with distance offshore (Figure 11), while nearshore environments support high abundances of calcareous green macroalgae throughout the area (Figure 12). A significant negative correlation between seagrass and calcareous macroalgal densities was found (Figure 13); however, no significant correlation exists between Thalassia testudinum and Syringodium filiforme densities. 


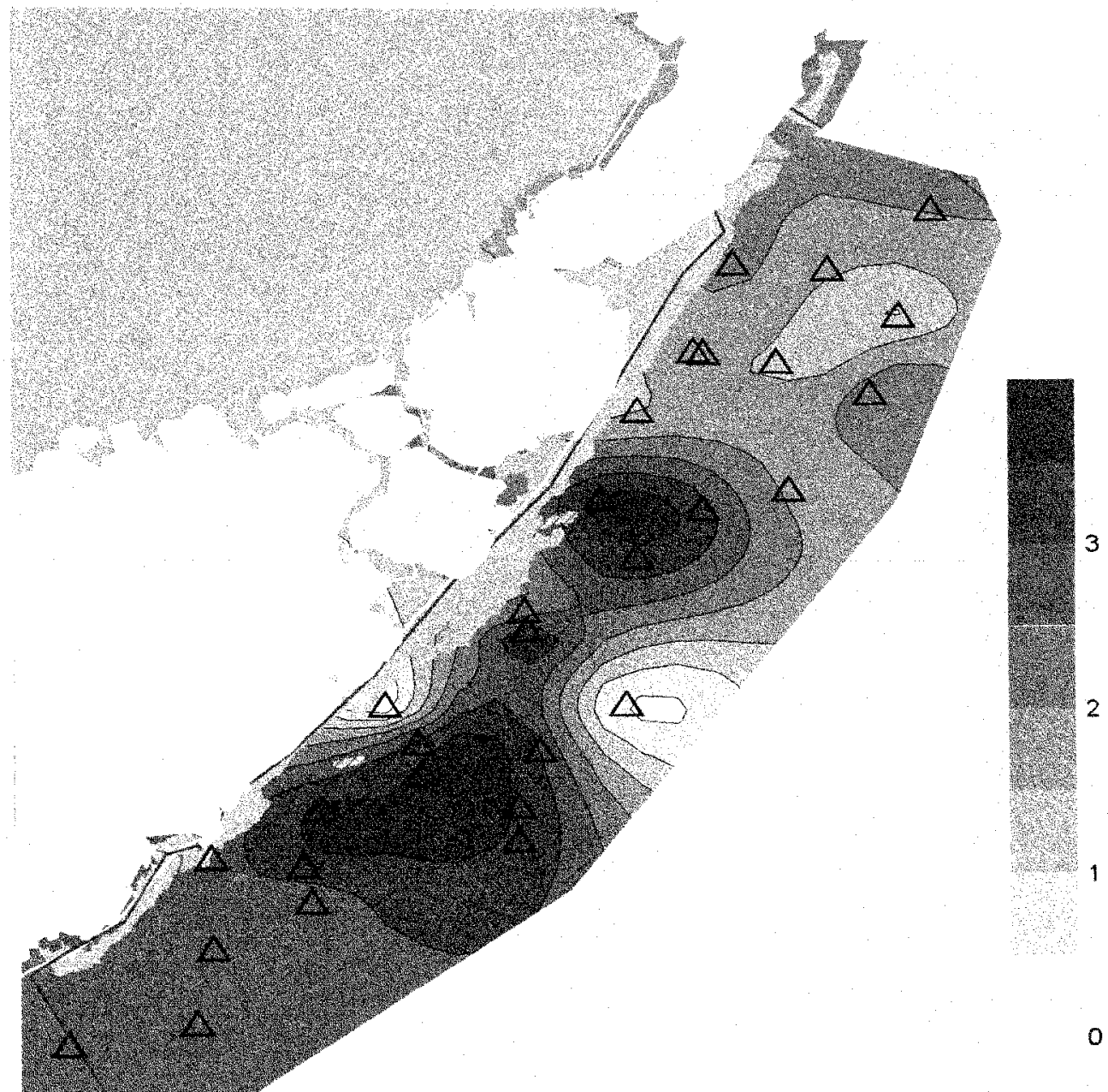

3

Braun-Blanquet Score

Figure 10. Thalassia testudinum abundance score distribution within Segment IX, FKNMS. 


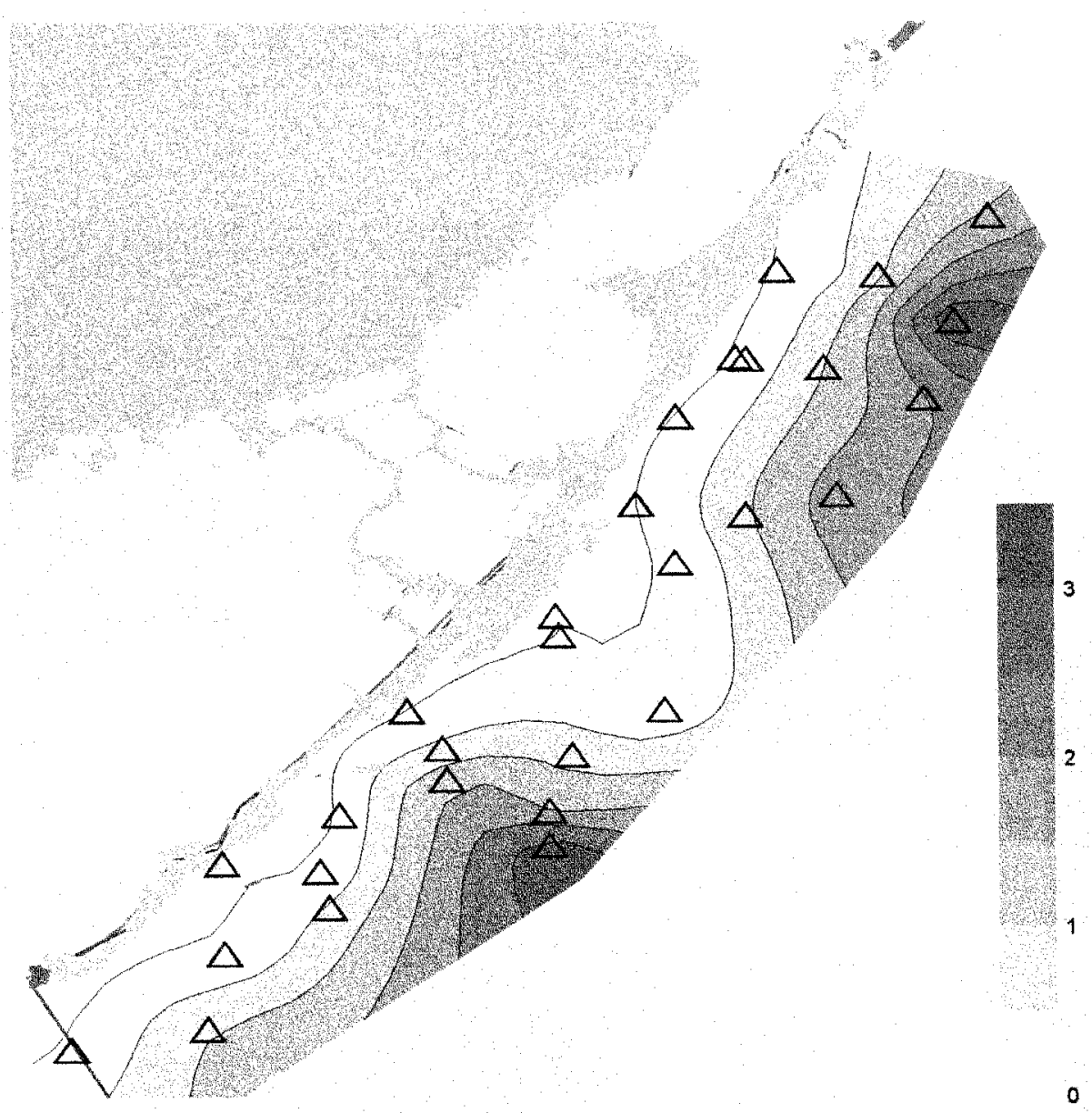

Braun-Blanquet Scale

Figure 11. Syringodium filiforme abundance score distribution within Segment IX, FKNMS. 


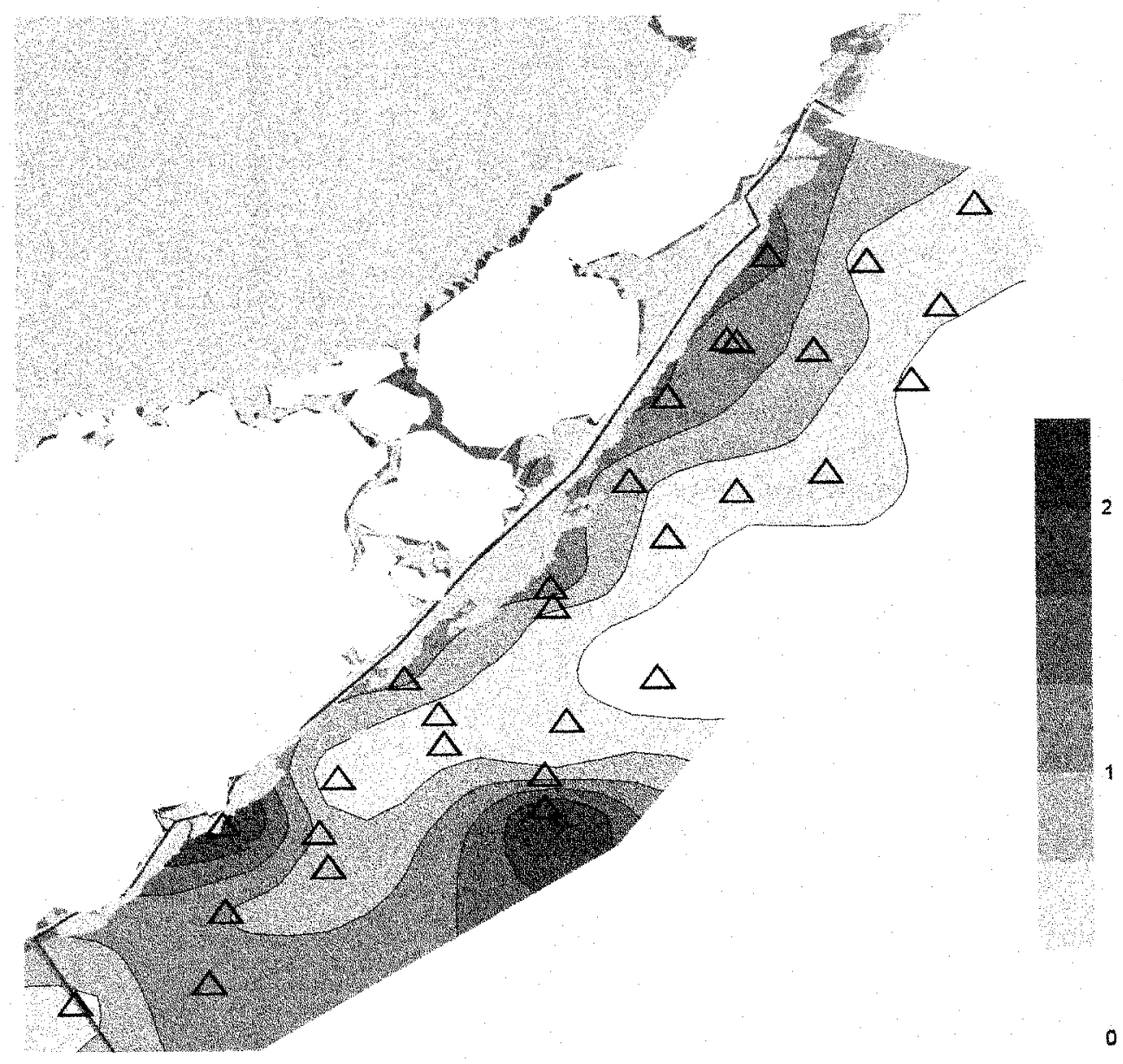

Braun-Blanquet Scale

Figure 12. Calcareous green macroalgal (Caulerpales) abundance score distribution within Segment IX, FKNMS. 
Thalassia testudinum vs. Calcareous Macroalgae

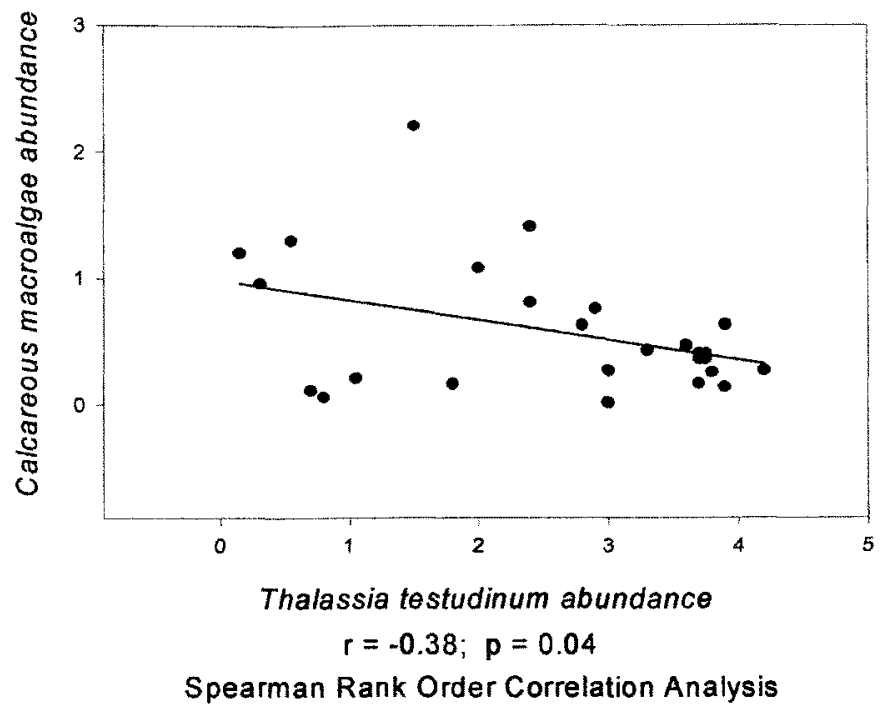

Syringodium filiforme vs. Calcareous Macroalgae

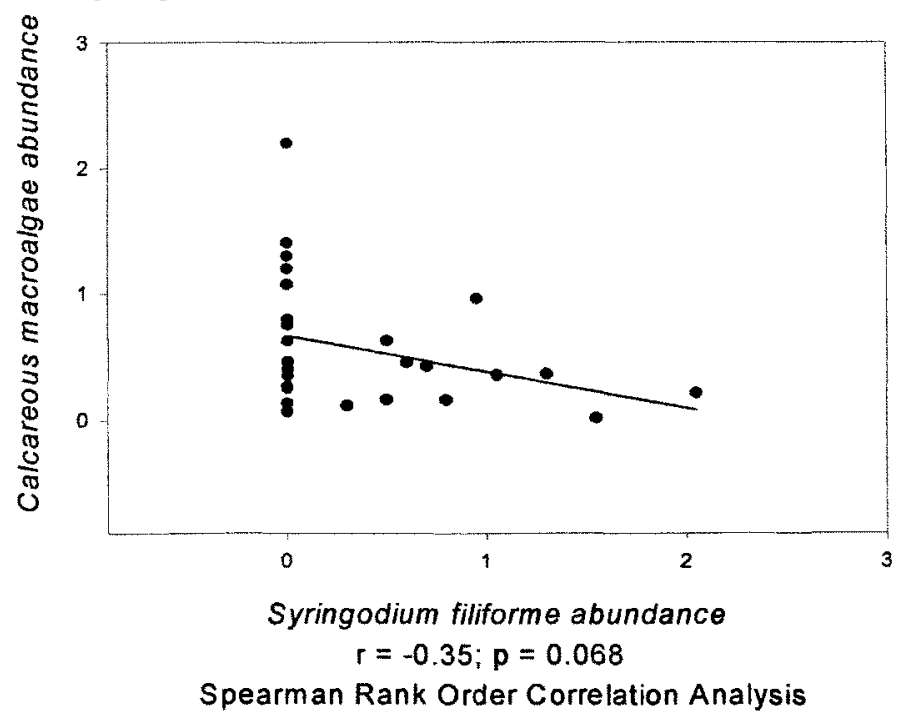

Figure 13. Large-scale correlation analysis of species abundances. 


\section{Small-Scale Spatial Analysis}

Spatial distributions of Thalassia testudinum, Syringodium filiforme and rhizophytic macroalgae did not correspond to the model presented in Figure 5 in any of the disturbances studied (Figure 14-16). T. testudinum increased with distance from the disturbances, and seems to level out after 15 m. S. filiforme increased linearly with increasing distance from the erosional scarps. Rhizophytic macroalgal densities increased initially, but leveled off at approxiamately $12 \mathrm{~m}$ (Figure 17).

Correlation analysis revealed significant positive correlations between Thalassia testudinum, Syringodium filiforme and rhizophytic macroalgal densities (Table 2). These correlations were obtained after pairwise deletions of 0,0 values, where quadrats were surveyed within the crescent sand patches. Many significant positive correlations also existed between individual macroalgal species (Table 3); however, the correlations were obtained by including quadrats sampled where neither species were found. 


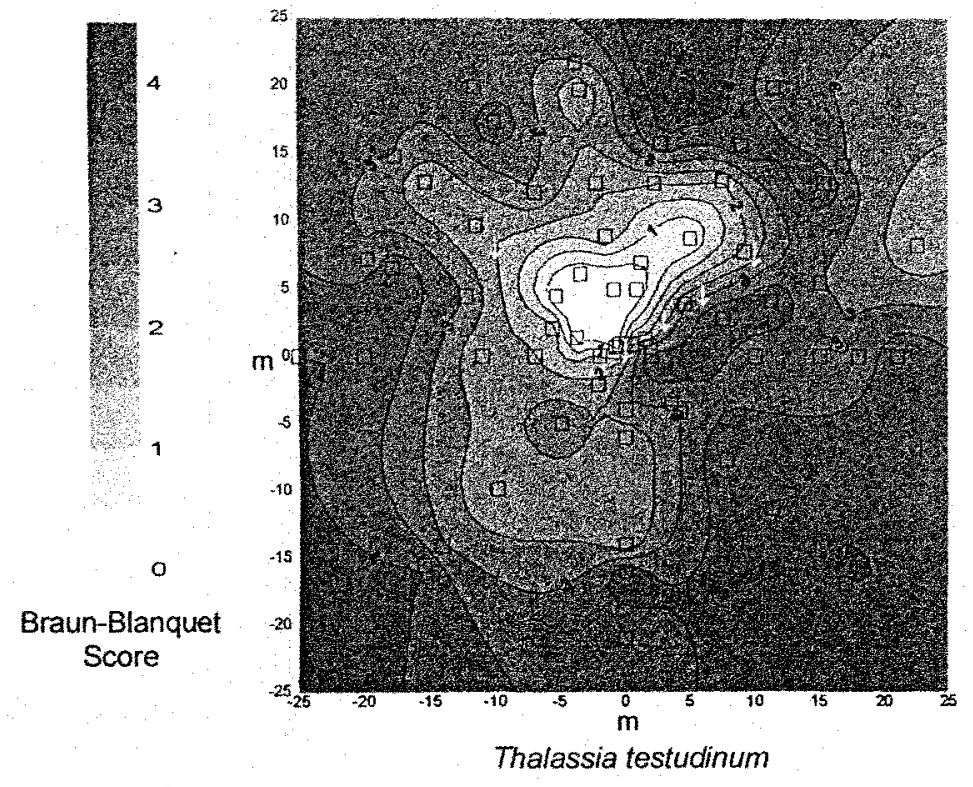

$\vec{N}$

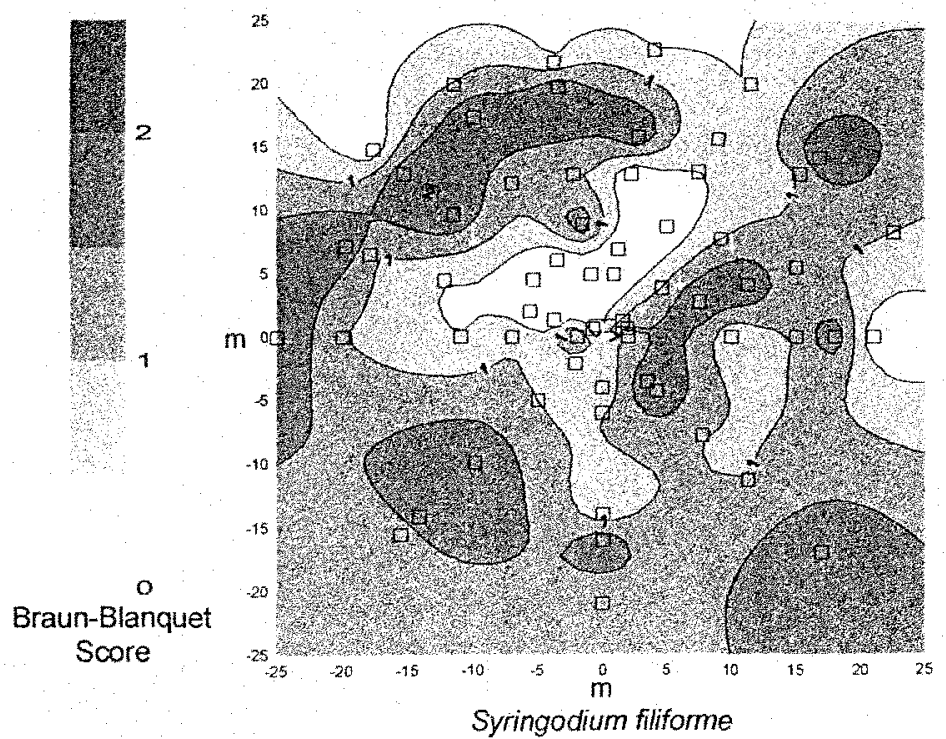

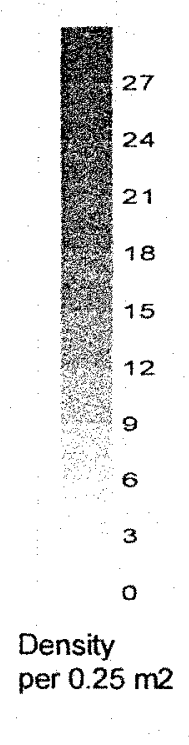

Figure 14. Species distributions around a blowout disturbance. Erosional scarp is in red, assumed migration is represented by arrows. Squares represent quadrat sampling locations. 


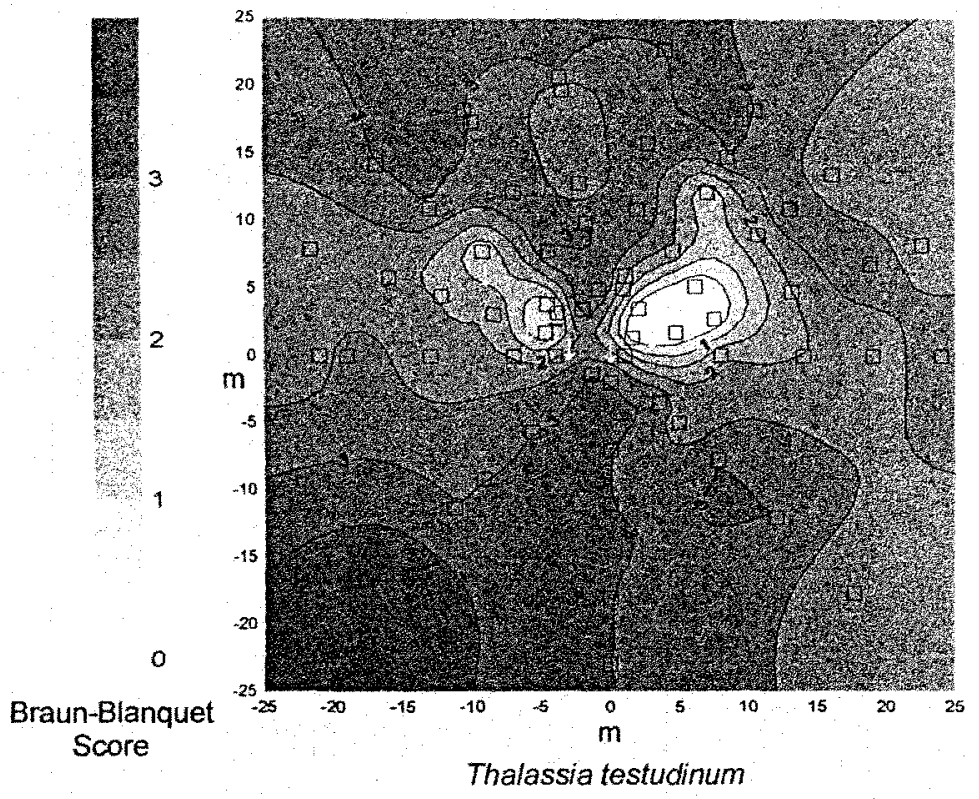

$\stackrel{t}{\omega}$

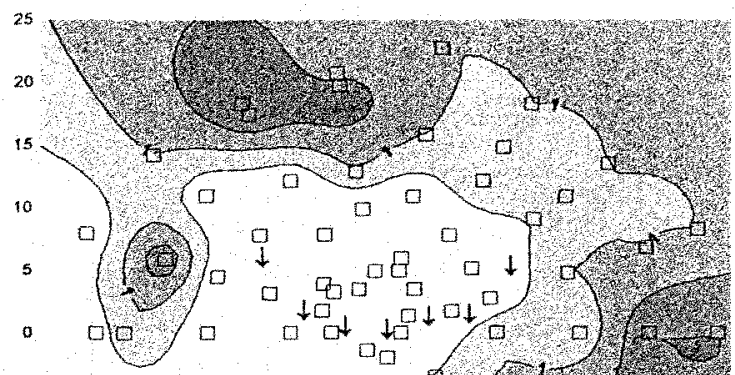

$\square$

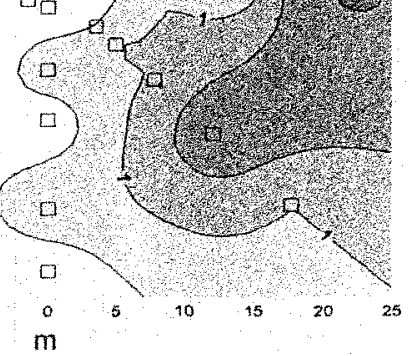

Braun-Blanquet Score
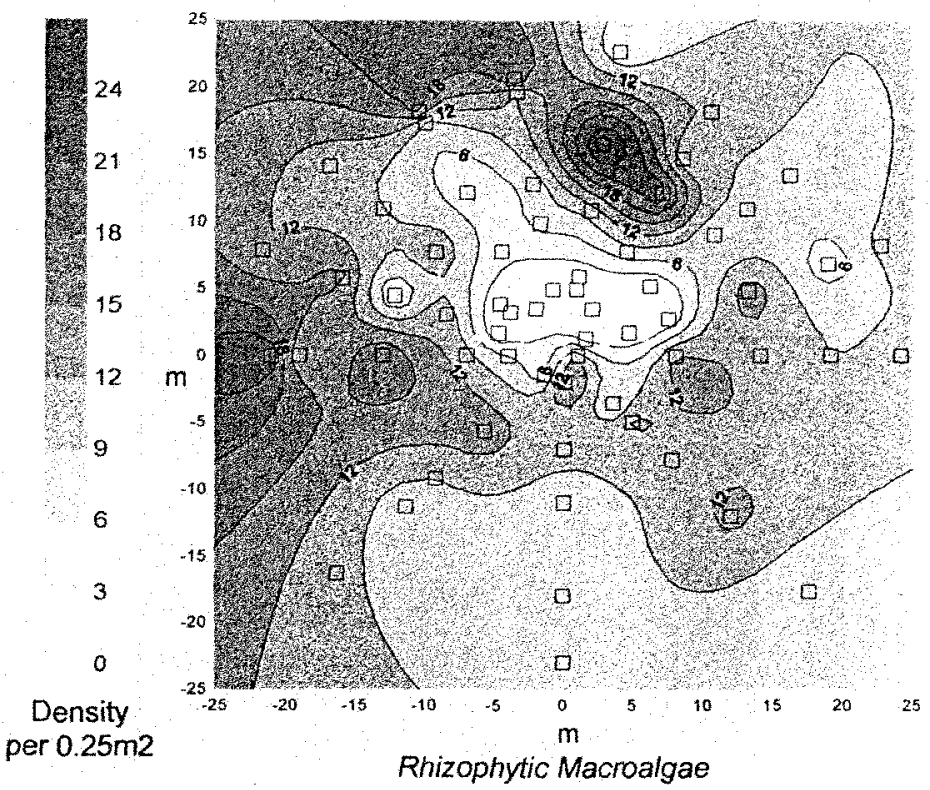

Figure 15. Species distributions around a blowout disturbance. Erosional scarp is in red, assumed migration is represented by arrows. Squares represent quadrat sampling locations. 


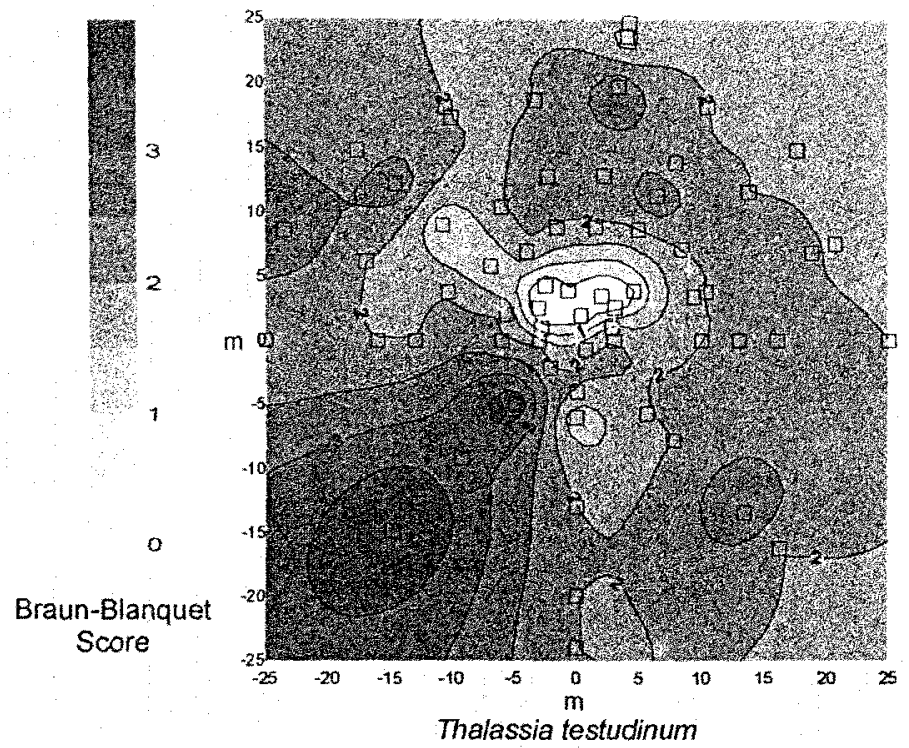

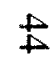

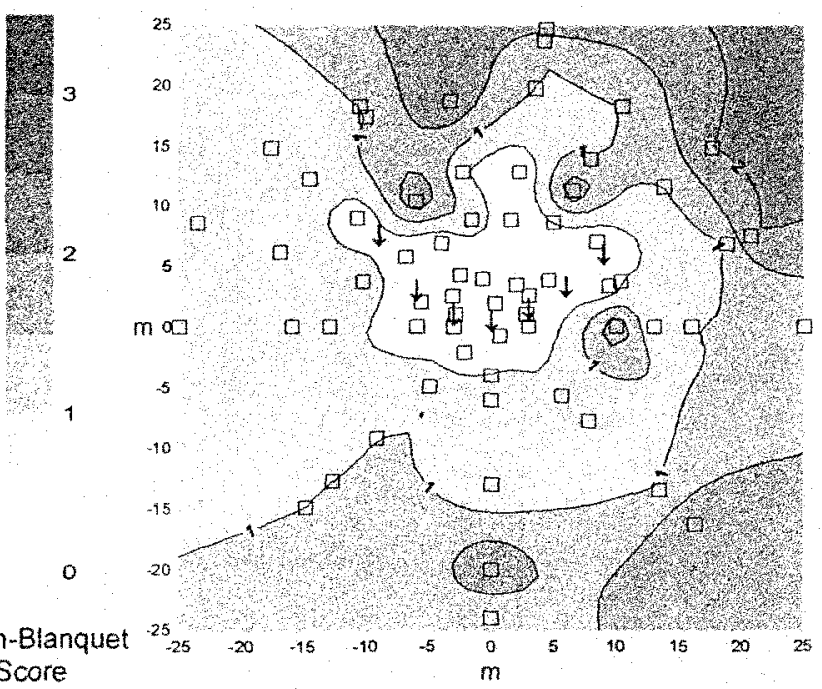

Syringodium filforme

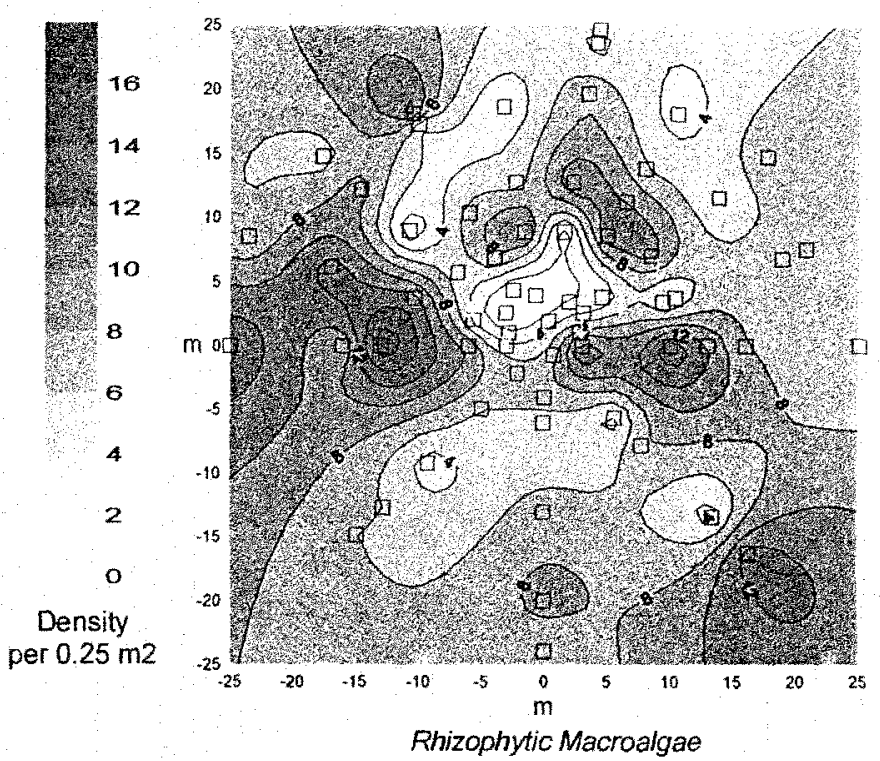

Figure 16. Species distributions around a blowout disturbance. Erosional scarp is in red, assumed migration is represented by arrows. Squares represent quadrat sampling locations. 


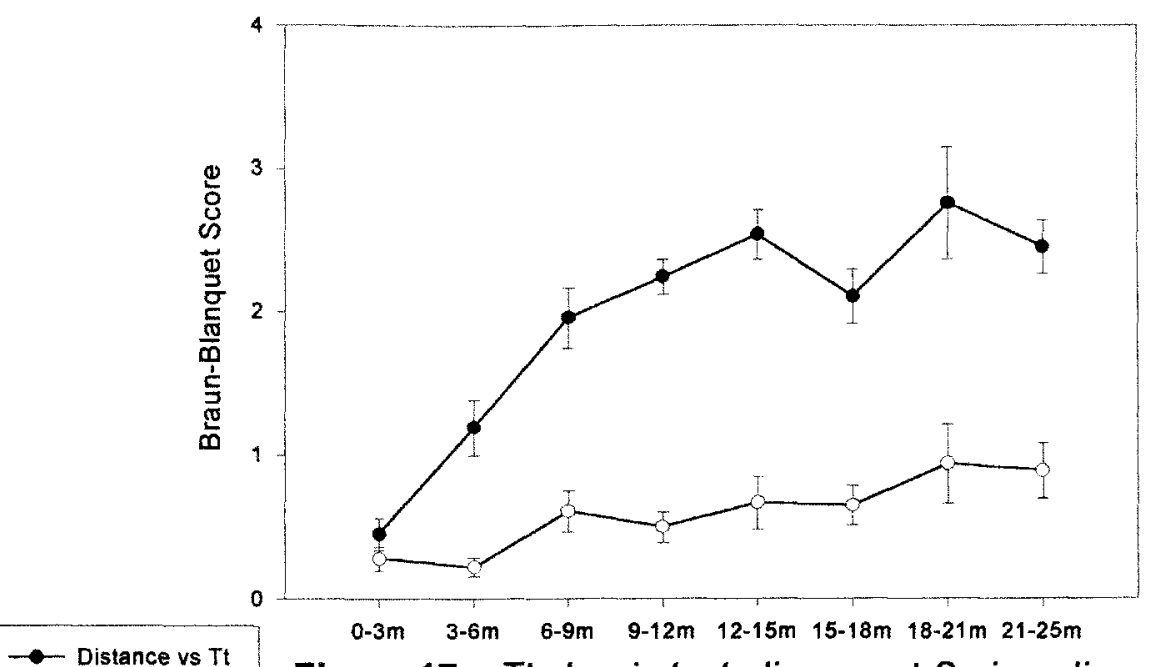

Figure 17a. Thalassia testudinum and Syringodium filiforme percent-cover estimates vs. distance from erosional scarp.

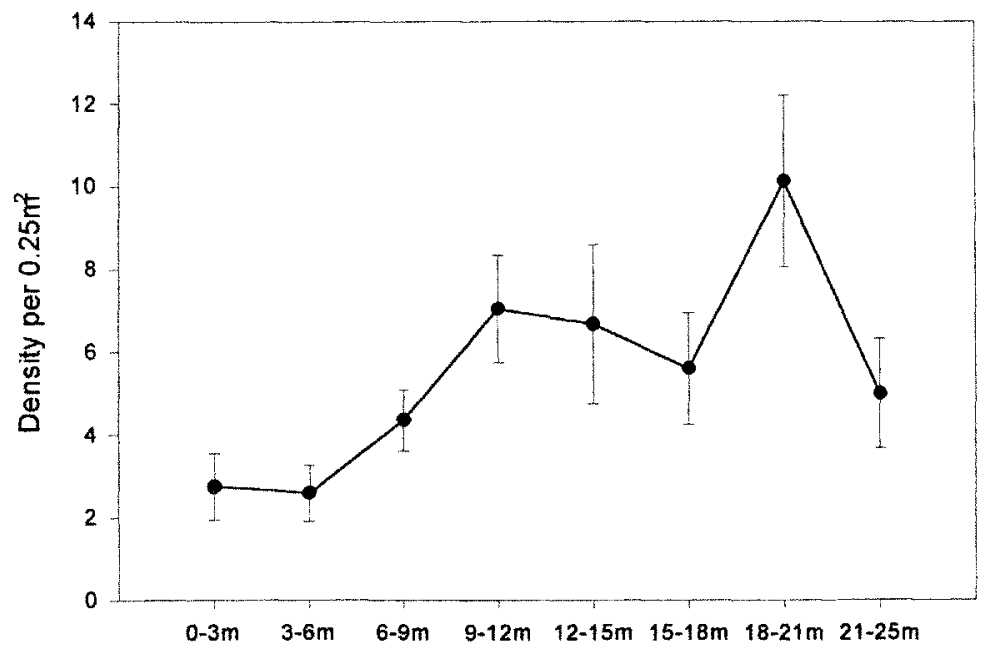

Figure 17b. Rhizophytic macroalgal densities vs. distance from erosional scarp.

Figure 17. Macrophyte recolonization following blowout disturbances. Graphs may be compared to the graphical model in Figure 6 . 


\begin{tabular}{|c|c|c|c|}
\hline Species & T. testudinum & S. filiforme & Rhizophytic algae \\
\hline T. testudinum & $\mathbf{1}$ & $\mathbf{0 . 0 0 1}$ & 0.001 \\
\hline S. filiforme & $\mathbf{0 . 2 2 0}$ & $\mathbf{1}$ & 0.001 \\
\hline Rhizophytic algae & $\mathbf{0 . 2 2 4}$ & $\mathbf{0 . 2 9 0}$ & $\mathbf{1}$ \\
\hline
\end{tabular}

Table 2. Spearman Rank Order Correlation matrix of seagrass and macroalgal densities over a small spatial scale, using pair-wise deletions of 0,0 values to eliminate the influence of the sand patch area of the disturbance. 


\begin{tabular}{|c|c|c|c|c|c|c|c|c|c|c|c|c|c|}
\hline & $T t$ & Sf & $\mathrm{Hi}$ & $\mathrm{Hm}$ & $H d$ & $A n$ & $P c$ & $P p$ & $P d$ & $R p$ & Uf & $C A$ & RA Total \\
\hline$T t$ & 1 & 0.001 & 0.001 & 0.001 & & & 0.001 & & & 0.001 & & & 0.001 \\
\hline Sf & 0.220 & 1 & 0.001 & 0.001 & & & 0.001 & & & & & & 0.001 \\
\hline $\mathrm{Hi}$ & 0.405 & 0.444 & 1 & 0.001 & & & & & & & & & 0.001 \\
\hline$H m$ & 0.256 & 0.258 & 0.271 & 1 & & & 0.021 & & & & 0.001 & & 0.001 \\
\hline$H d$ & 0.023 & -0.046 & -0.005 & 0.074 & 1 & & & & & & & & \\
\hline$A n$ & 0.068 & -0.097 & -0.072 & -0.082 & -0.052 & 1 & & & & 0.001 & & & 0.001 \\
\hline$P c$ & 0.198 & 0.161 & 0.082 & 0.108 & -0.098 & 0.052 & 1 & & & & 0.029 & & 0.001 \\
\hline$P p$ & 0.087 & 0.047 & 0.086 & 0.079 & -0.016 & -0.013 & -0.013 & 1 & & & 0.003 & & 0.001 \\
\hline$P d$ & 0.020 & -0.031 & 0.038 & 0.021 & 0.015 & 0.089 & 0.028 & -0.012 & 1 & & & & 0.02 \\
\hline$R p$ & 0.162 & 0.037 & 0.072 & -0.022 & -0.011 & 0.154 & 0.086 & 0.039 & -0.021 & 1 & & & 0.001 \\
\hline Uf & 0.084 & 0.091 & 0.079 & 0.178 & -0.016 & 0.013 & 0.102 & 0.140 & -0.020 & 0.094 & 1 & & 0.001 \\
\hline $\mathrm{Ca}$ & 0.049 & 0.026 & -0.037 & -0.015 & 0.073 & 0.023 & 0.009 & 0.099 & -0.035 & -0.008 & 0.031 & 1 & \\
\hline A Tote & 0.240 & 0.290 & 0.738 & 0.564 & -0.029 & 0.192 & 0.514 & 0.152 & 0.109 & 0.265 & 0.373 & 0.015 & \\
\hline
\end{tabular}

Table 3. Spearman Rank Order Correlation matrix of seagrass and macroalgal densities over a small spatial scale. Significant correlations are in bold (bottom half), significance values (top half). Codes represent species present: Thalassia testudinum, Syringodium filiforme, Halimeda incrassata, $H$. monile, $H$. discoidea, Avrainvillea nigricans, Penicillus capitatus, Penicillus pyriformis, Penicillus dumetosus, Rhipocephalus phoenix, Udotea flabellum, Caulerpa sp. (not abundant), and rhizophytic algal totals. 


\section{DISCUSSION}

The abundances of seagrasses and calcareous green macroalgae of the order Caulerpales are negatively correlated over the upper Florida Keys region. It is suggested that an interspecific interaction could be responsible for limiting the species abundances. The significant negative correlations found lend evidence toward a competitive interaction between tropical seagrasses and rhizophytic macroalgae over a regional scale. The finding is consistent with the existence of competitive interactions between these taxa (Chapter 3; Williams, 1990), but is not in itself sufficient proof of such an interaction.

Williams (1990) found decreasing macroalgal densities in experimental disturbance plots once Thalassia testudinum recolonization had reached a minimum density. Species manipulations in Chapter 3 resulted in significant growth responses that also implicated competitive interactions between Thalassia testudinum and a representative rhizophytic macroalga. All of these findings support the successional sequence first described by den Hartog (1971) as consisting of species turnover events that are based on competitive exclusion by $T$. testudinum. 
The large-scale spatial analysis was subject to an important limiting assumption. At each sampling station, I assumed that all of the macrophyte species had, over time, an equal probability of colonization, growth and reproductive success. If this assumption is met, then interspecific interactions would govern any correlations between species densities. If the assumption is invalid, then the success of each species would be more related to independent limiting resources which make some habitats less favorable than others. For example, I previously mentioned that the relative uptake of sediment and water column nutrients is not completely known for the seagrasses or macroalgae. If one species requires greater water column sources than another that utilizes mainly sediment sources, then a negative correlation could exist between the species densities due to water column gradients in nutrient supply, even though the presence or absence of one species does not affect the other. In defense of the assumption, both groups colonize the shifting sediments throughout the region and are usually found together (pers. obs). Sediment and water column nutrient sources are highly correlated in the area (Fourqurean et al. 1992b; Fourqurean et al. 1993), so that differential resource acquisition may not dictate species distributions. Finally, net organic production per individual seagrass shoots and rhizophytic 
macroalgae has been shown to be roughly equal (Chapter 3), so that nutrient demands may be similar between groups.

At a smaller spatial scale around localized disturbances, species densities were not negatively correlated. However, the proposed successional sequence, where species turnover events are thought to result from competitive interactions (Zieman, 1982; Williams, 1990), was not found around the trailing edges of these disturbances. A similar analysis around disturbances in other areas may follow the predicted results, but it is interesting to note that the blowouts studied here did not correspond well to descriptions within the literature (Patriquin, 1975; Zieman, 1982).

When comparing the contour maps generated of three of the seven blowouts (Figures 14-16) with the contour model in Figure 5, the first evidence of a lack of species zonations in the area becomes apparent. After binning species density data into distance from disturbance classes and plotting the values, I compared graphically the recolonization sequence I found (Figure 17) with the sequence described in the literature (Figure 6). Again, no evidence was found for species zonations or successional species turnover events. Rather than negative correlations between Thalassia testudinum, Syringodium filiforme and rhizophytic macroalgal densities that 
should result from such species zonations, I found significant positive correlations that may be expected with increasing densities during recolonization.

There are several plausible explanations for the discrepancy. First, the large-scale spatial patterns may not result from localized competitive interactions; or, the large-scale assumption of equal probability of success for all species may be invalid. Next, the blowouts may not have migrated. Blowout migration was assumed based on several other studies (Patriquin, 1975; Wanless, 1981), but has yet to be measured in this area. If so, then each crescent sand patch represents an on-going disturbance that creates a species density gradient that increases with distance from the disturbance, and decreases the importance of interspecific interactions nearby. Third, the spatial scale studied may not have encompassed a large enough area to detect species zonations. However, based on the "before and after" view attained from the additional transects run at the disturbances presented in Figures 1416 , the $25 \mathrm{~m}$ spatial scale was sufficient to show a lack of species zonations around each blowout. Relative densities before each blowout is assumed to have migrated across a seagrass bed are roughly equal to those following the disturbances, suggesting that increased transect distances from the blowouts would not have yielded any opposing evidence for species zonations. 
A final explanation is that stresses associated with increased wave energy or increased herbivorous activity from nearby reefs create a level of intermediate disturbance described in a similar blowout area in Australia (Kirkman, 1985). The study suggested that the intermediate disturbance level associated with blowouts resulted in a high level of seagrass species diversity. In this study area, rhizophytic macroalgal species diversity appears very high relative to other community types within the Florida Keys National Marine Sanctuary (pers. obs.), and two of the three local seagrass species are also found herein. This disturbance level may not lower the number of species able to colonize the area, but may lower species' densities, resulting in weakened effects of interspecific interactions. Weak interactions could have lead to a lack of species zonations in the area, as Thalassia testudinum does not competitively exclude Syringodium filiforme within the blowout area. Despite the lack of small-scale spatial evidence, this study lends evidence towards a competitive interaction model between tropical seagrasses and rhizophytic macroalgae. This, combined with experimental evidence presented in Chapter 3, should fill a gap in our knowledge of interspecific interactions between the dominant macrophytes of these systems. The information contributes to a better understanding of the processes dictating community composition in tropical seagrass meadows. 
Chapter 3

\title{
Determining species interactions between the tropical alga, Halimeda incrassata, and the seagrass, Thalassia testudinum.
}

\begin{abstract}
Possible interactions between rhizophytic macroalgae of the order Caulerpales and seagrasses are reported in tropical seagrass literature. This study represents the first experimental investigation of interspecific interactions operating between the dominant seagrass and an abundant rhizophytic macroalga within a mature seagrass community. Treatments consisted of density manipulations of the dominant seagrass species, Thalassia testudinum, and of the most common representative of the rhizophytic algae, Halimeda incrassata. Evidence of interaction was measured by changes in relative shortterm productivity and biomass of both algae and seagrass over a fourmonth period. No significant changes were detected in T. testudinum growth rates; however, average above-ground dry weight was significantly higher in algal removal plots relative to algal addition plots. A significant increase in $\mathrm{H}$. incrassata growth rate and average above-ground dry weight was found in T. testudinum removal plots. Nitrogen and light limitation were investigated as possible underlying mechanisms of the interaction. Seagrass leaf tissue $C: N$ was significantly lower $(p=0.06)$ in algal removal treatments. No significant treatment effect was demonstrated for substrate-level irradiance. The changes in algal short-term growth rates and average dry weights, along with the change in seagrass average dry weights, support a competitive interaction theory for T. testudinum and rhizophytic macroalgae.
\end{abstract}


Rhizophytic macroalgae of the order Caulerpales make up a substantial component of the dominant macrophyte communities forming tropical seagrass meadows. These are the primary macroalgal species capable of colonizing the shifting sediments which seagrasses occupy. Although possible mechanisms of interaction between these macroalgae and seagrasses have been suggested in the literature (den Hartog, 1971; Patriquin, 1975; McRoy and Lloyd, 1981; Zieman, 1982; Multer, 1988; and Williams, 1985, 1988), attempts at field experimentation or observational analysis concerning possible interactions are limited. Williams (1990) demonstrated a decline in macroalgal densities as seagrasses became reestablished, suggesting a competitive interaction. Multer (1988) observed the highest rhizophytic macroalgal productivities in areas of low to medium seagrass densities, lending additional indirect evidence of competition. In Chapter 2, I found a negative correlation between rhizophytic macroalgal densities and Thalassia testudinum cover over a large spatial scale, again suggesting a competitive interaction. This study is the first experimental investigation of a possible competitive interaction between these species within a mature seagrass community.

For the experimental analysis of seagrass and rhizophytic macroalgal interaction, it was necessary to select representative species from each group. 
I chose to use Halimeda incrassata Lamouroux as a representative of the rhizophytic macroalgae for a number of reasons. First, during a preliminary analysis, I found that this species recovered well after transplantation. In addition, new growth over time was easier to measure relative to other rhizophytic macroalgae. Most importantly, $H$. incrassata is the most abundant representative of the rhizophytic green algal species found within this and many other tropical seagrass systems (Multer, 1988; Williams, 1990; Freile and Hillis, 1997). I were also primarily interested in the seagrass, Thalassia testudinum Banks ex König, as it is the most abundant neotropical seagrass species and is usually considered the dominant producer in latesuccessional or climax seagrass communities (den Hartog, 1971).

Before investigating possible interspecific interactions, I first distinguish the basic differences in morphologies, life history strategies and resource acquisition strategies between these macrophytes. These differences can produce trade-offs in colonization potential, longevity, and competitive ability (Tilman, 1994). These trade-offs are important when considering potential interspecific interactions.

Thalassia testudinum expands horizontally with rhizomes, producing root bundles and lateral buds at regular intervals. These buds become vertical short-shoots with photosynthetic foliage leaves which usually reach heights of 
10-25 cm. Rhizomes are found buried $5-25 \mathrm{~cm}$ in the sediment. Horizontal rhizome expansion occurs via apical meristems, and branches may occur from vertical shoots (Tomlinson and Vargo, 1966). The seagrass has relatively slower growth, greater longevity (Gallegos et al., 1993) and lower reproductive investment (review in Moffler and Durako, 1987) than the rhizophytic macroalgae.

Rhizophytic macroalgae anchor themselves in the sediment with a rhizoid bulb. Interwoven, coenocytic filaments make up an erect thallus which is photosynthetic to varying degrees and supports a photosynthetic frond. Most of the algae secrete a calcareous exoskeleton, which may comprise $20-90 \%$ of its total dry weight (Bach, 1979; Multer, 1988; present study). The macroalgal species are considered the pioneers of the successional sequence, with rapid turnover rates (Wefer, 1980; Freile and Hillis, 1997), shorter longevities (Bach, 1979), and greater investments in reproduction (Clifton, 1997). Halimeda incrassata has a thallus supported by a rhizoid bulb which is buried within the sediment. Branches from the thallus are made up of thin, photosynthetic, calcified segments which are linked together by small, non-calcified joints.

Nutrient uptake and translocation in both seagrasses and rhizophytic macroalgae is not yet fully understood, particularly in reference to the relative 
importance of sediment vs. water column sources. Patriquin (1972) claimed that a significant portion of phosphorus and virtually all nitrogen for Thalassia testudinum leaf growth was taken up from the sediment. Williams (1990) reviews several studies which build evidence suggesting that T. testudinum development is largely limited by sediment nutrient availability. However, some studies have shown that the relative role of leaf versus root uptake of nutrients is not completely understood, and may vary with the presence of alternate sources. Furthermore, nutrients may be taken up by seagrass leaves as they diffuse out of the sediments, which could impede detection of sediment vs. water column sources (for review see Hemminga et al., 1991). Stapel et al. (1996) found that the availability of nitrogen and phosphorus in the root and leaf zone affected the uptake affinity of the leaves of Thalassia hemprichii, and that leaf uptake may be essential for growth even in oligotrophic waters.

Most marine algae take up nutrients entirely from the water column and have no root-like structures within the sediment, rather they utilize small holdfasts to hard substrates or drift freely. However, Williams (1984) found that the rhizophytic algal species Halimeda incrassata, Halimeda monile, and Penicillus capitatus were capable of translocating porewater nutrients from 
rhizoids into the thallus. Relative resource requirements of individual seagrass shoots and macroalgae have not yet been documented.

Based on the previous observations in the literature, I hypothesized that these species maintain would compete within mature seagrass communities. I tested this hypothesis by measuring growth responses of both the macroalga and seagrass relative to density manipulation treatments. Seagrass average size and growth rates are expected to decline in algal addition plots relative to algal removal plot; while algal average size and growth rates are expected to increase in seagrass removal plots relative to controls.

\section{MATERIALS AND METHODS}

Study Area

The seagrass meadow studied was within John Pennekamp Coral Reef State Park, approximately 3 nautical miles offshore of upper Key Largo in the Florida Keys, two nautical miles inshore of the main reef tract, in $7 \mathrm{~m}$ of water. The site was selected based on high densities of Halimeda incrassata and Thalassia testudinum, and low densities of other species encountered. The seagrass bed was dominated by Thalassia testudinum, with densities of 
$400-800 \mathrm{shoots} / \mathrm{m}^{2}$. Halimeda incrassata was by far the most abundant rhizophytic macroalgal species, with an average density of 100 thalli $/ \mathrm{m}^{2} . H$. monile was common, with an average density of 24 thalli $/ \mathrm{m}^{2}$. Densities of other macroalgal species were negligible.

\begin{tabular}{l|ccc}
\hline Treatment & July 8, 1997 & September 8, 1997 & November 7, 1997 \\
\hline Algal Removals & 3 & 3 & 3 \\
Algal Additions & 3 & 3 & 3 \\
Seagrass Removals & 3 & 3 & 3 \\
Controls & 3 & 3 & 3 \\
\hline
\end{tabular}

Table 4. Experimental design showing number of plots assigned per treatment, per destructive sampling event. 
Experimental Design

I measured changes in short-term growth rates and biomasses during three sampling events, over a four-month period. Treatments consisted of: 1) the complete removal of Halimeda incrassata; 2) the doubling of the average density of $H$. incrassata; 3) the complete removal of Thalassia testudinum; and 4) control quadrats. Additions of $T$. testudinum were not attempted due to the difficulties involved in transplanting this more structurally complex species (see Table 4).

Treatments were assigned to thirty-six $0.25 \mathrm{~m}^{2}$ quadrats were made from PVC tubing, 9 quadrats for each of the four treatments. The quadrats were shuffled between three divers and randomly laid out in a six by six grid, with approximately $1.5 \mathrm{~m}$ of separation between quadrats. In control and seagrass removal quadrats, densities of Halimeda incrassata were controlled at the local density level of 25 thalli per $0.25 \mathrm{~m}^{2} \mathrm{plot}$, which sometimes involved the removal or addition of a few thalli. Any other algae found within the quadrats were removed. For seagrass removal plots, vertical shoots were plucked from the horizontal rhizomes, which were left in place in order to minimize disturbance to the plot. I used a saw to cut $50 \mathrm{~cm}$ into the substrate around the perimeter of these quadrats in order to sever outside rhizome 
connections, eliminating any possible translocation into or out of the quadrats.

For the $H$. incrassata density-doubling treatment, thalli of average height $(\sim 12 \mathrm{~cm})$ were transplanted into each quadrat from the immediate area, producing a total density of 50 thalli per $0.25 \mathrm{~m}^{2}$ plot.

Productivity measurement techniques

To measure the short-term production rates of the seagrasses and algae simultaneously, I used two established techniques which measure new growth over time by establishing a marker separating new and old growth. First, I used Zieman's (1974) leaf-punching technique to mark the existing shortshoot leaves at their base with a needle. The leaves were harvested after a period of seven to nine days. Because their growth is basal, all new growth was formed under the marking scar and could easily be separated from old growth. Blade growth was quantified both by dry weight and by leaf-area production measurement.

I used a similar marking technique for calcareous macroalgae that utilized the incorporation of a stain, Alizarin Red S, into the calcium carbonate shell (Wefer, 1980; Multer, 1988; Freile and Hillis, 1997). The stain is incorporated into the living plants as a consequence of calcification, staining the algae pink-red. The dye is removed, and subsequent growth adds 
new white $\mathrm{CaCO}_{3}$ material. The algae is then harvested and bleached. Each alga's old growth is stained pink or red, and all new growth is white. In the experiment, new growth was quantified by dry weight of new segments. By using these marking methods, both the seagrass and macroalgal productivities were measured as new growth over time.

I collected 45 random thalli of Halimeda incrassata in a neighboring area for measurement of percent calcium carbonate of the segments. These were cleaned by hand, rinsed, dried and weighed for total dry weight, and subsequently ashed for $3 \mathrm{hrs}$ at 500 degrees $\mathrm{C}$. The ash weight is equal to the dry weight of the calcium carbonate, which then yields a value for the percent organic material per thallus called the ash-free dry weight.

\section{Sampling methodology}

The study ran from July through November, 1997, with three sampling events: initially, after 2 months and after 4 months. The first sampling event took place one day after the site establishment. During each sampling event, the same sequence of work took place. First, the macroalgae in three replicates of algal doubling, seagrass removal and control quadrats were covered with weighted, clear plastic $240 \mathrm{~mL}$ cups. These were injected with $20 \mathrm{cc}$ of a solution of $5 \mathrm{~g}$ Alizarin Red S/ liter distilled water (stain does not 
dissolve well in salt water, so a minimum of distilled water was injected into each cup). After $24 \mathrm{~h}$, the cups were removed. Next, all of the seagrass shoots within two $10 \times 20 \mathrm{~cm}$ subquadrats were marked within the same three replicate algal doubling and control quadrats, and in three replicate algal removal quadrats. The macroalgae and seagrasses were left to grow over the following 7-9 days. During harvesting, all biomass was collected from within each quadrat in order to determine average above-ground dry weights of seagrasses and macroalgae.

In order to measure potential mechanisms of the interaction, I sacrificed five shoots of Thalassia testudinum all quadrats (excluding Seagrass Removal quadrats) during the sampling event for each quadrat. Leaves from these were ground to a fine powder and analyzed for tissue carbon:nitrogen using a Carla-Erba 1500 series nutrient analyzer. In addition, I measure the percent of canopy-level irradiance reaching the substrate level by using a QSI-140 light probe. I sampled three quadrats of each treatment, and took four measures of canopy and substrate-level irradiance over 15second intervals for each quadrat. 
A) Because algal growth and biomass measures were not collected within algal addition plots within the first sampling event, I used a $2 \times 3$ factorial analysis of variance to test for significant changes in biomasses or growth rates of Halimeda incrassata; with the treatment factor having the levels of Seagrass Removal and Control, and the sampling event factor having the levels of 0,2 , and 4 months.

B) An additional $3 \times 2$ factorial analysis of variance was used to test for significant changes in biomasses or growth rates of Halimeda incrassata; with the treatment factor having the levels of Seagrass Removal, Algal Addition, and Controls, and the sampling event factor having the levels of 2 and 4 months.

C) Seagrass biomasses and production rates were compared with a $3 \times 3$ factorial analysis of variance, with the treatment factor having the levels of Algal Removal, Algal Addition, and Control, and the sampling event factor having the levels of 0,2 and 4 months.

D) Seagrass leaf tissue carbon:nitrogen was also tested for significant treatment and time effects using a $3 \times 3$ factorial ANOVA. Substrate-level irradiance was tested for significant treatment effects only using a one-way ANOVA. 


\section{RESULTS}

\section{Growth rates of Thalassia testudinum and Halimeda incrassata}

Thalassia testudinum had a mean production of $1.47 \pm 0.086 \mathrm{mg}$ shoot $^{-1}$ day $^{-1}$ over the course of the study. The Halimeda incrassata that I collected during a preliminary analysis in the area were $80.6 \% \pm 0.5 \%$ $\mathrm{CaCO}_{3}$. Based on this, the net above-ground organic production of $H$. incrassata averaged $1.50 \pm 0.069 \mathrm{mg}$ thallus ${ }^{-1} \mathrm{day}^{-1}$ over the course of the study, roughly equal to that of an individual shoot of Thalassia testudinum (Table 5). Based on average densities within the study area, this aboveground organic production results in $18.1 \%$ of the aerial carbon production of T. testudinum. In the study area, $T$. testudinum produces approximately 829 $\mathrm{mg} \mathrm{m}^{-2}$ day $^{-1}$, while the macroalgae contribute approximately $150 \mathrm{mg} \mathrm{m}^{-2}$ day $^{-1}$. The algal growth rates reported in all other figures and tables include calcium carbonate production. 


\section{Halimeda incrassata Response}

The removal of seagrasses had a positive impact on sizes and growth rates of Halimeda incrassata. Thallus-specific mean growth rates for Seagrass Removal and Control plots were $10.457 \pm 2.00$ and $7.010 \pm 0.71 \mathrm{mg} \mathrm{day}^{-1}$ thallus $^{-1}$, respectively, (Figure 18), and were significantly different [Treatment main effect, $F=4.8 ;$ d.f. $=1,12 ; p=0.05$, Table 6]. The July, September and November mean growth values were $12.329 \pm 1.10,6.512 \pm 0.45$ and 7.359 $\pm 0.729 \mathrm{mg} /$ day, respectively. The July growth rates were significantly higher than those during subsequent sampling events [Event main effect, $F=5.3$; d.f.= 2,$12 ; p=0.02$, Table 6].

Averaged across September and November sampling events only, algal growth rates were again significantly higher in Seagrass Removal plots [Treatment main effect, $F=10.38 ;$ d.f. $=2,12 ; p=0.00$, Table 7]. Mean thallusspecific growth rates were $8.996 \pm 0.63,5.37 \pm 0.42$, and $4.875 \pm 0.39 \mathrm{mg} /$ day for Seagrass Removals, Algal Additions, and Controls, respectively (Figure 18). September growth rates were significantly lower than November growth rates, averaging $5.417 \pm 0.34$ and $7.410 \pm 0.511 \mathrm{mg} /$ day, respectively [Event main effect, $\mathrm{F}=6.1 ;$ d.f. $=1,12 ; \mathrm{p}=0.03$, Table 7]. 
Mean individual dry weights in Seagrass Removal and Control plots were

$1.432 \pm 0.057$ and $1.126 \pm 0.048 \mathrm{~g}$, respectively (Figure 19), and were significantly different $[$ Treatment main effect, $F=7.5 ;$ d.f. $=1,12 ; p=0.02$, Table 8]. The July, September and November mean values were $1.145 \pm 0.06$, $1.388 \pm 0.068$ and $1.304 \pm 0.068 \mathrm{~g}$, respectively, and were not significantly different [Event main effect, $F=1.6 ;$ d.f. $=2,12 ; p=0.24$, Table 8].

Average dry weights for Seagrass Removals, Algal Additions, and Controls during the September and November sampling events were 1.587 $\pm 0.076,1.319 \pm 0.065$ and $1.105 \pm 0.051 \mathrm{~g}$, respectively, and were significantly different [Treatment main effect, $F=4.79 ;$ d.f. $=2,12 ; p=0.030$, Table 9]. September and November values were $1.337 \pm 0.055$ and $1.338 \pm 0.055 \mathrm{~g}$, respectively, and were not significantly different [Event main effect, $\mathrm{F}=0$; d.f. $=1,12 ; p=0.993$, Table 9]. 


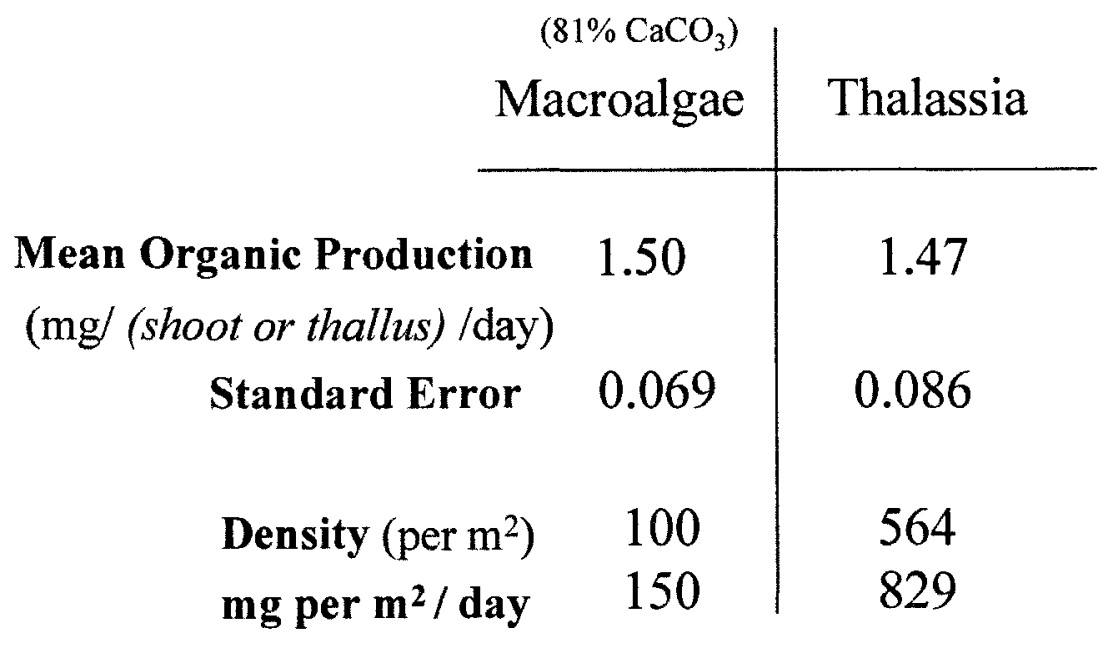

Table 5. Comparison of net production by individual Halimeda incrassata thalli and individual shoots of Thalassia testudinum. 


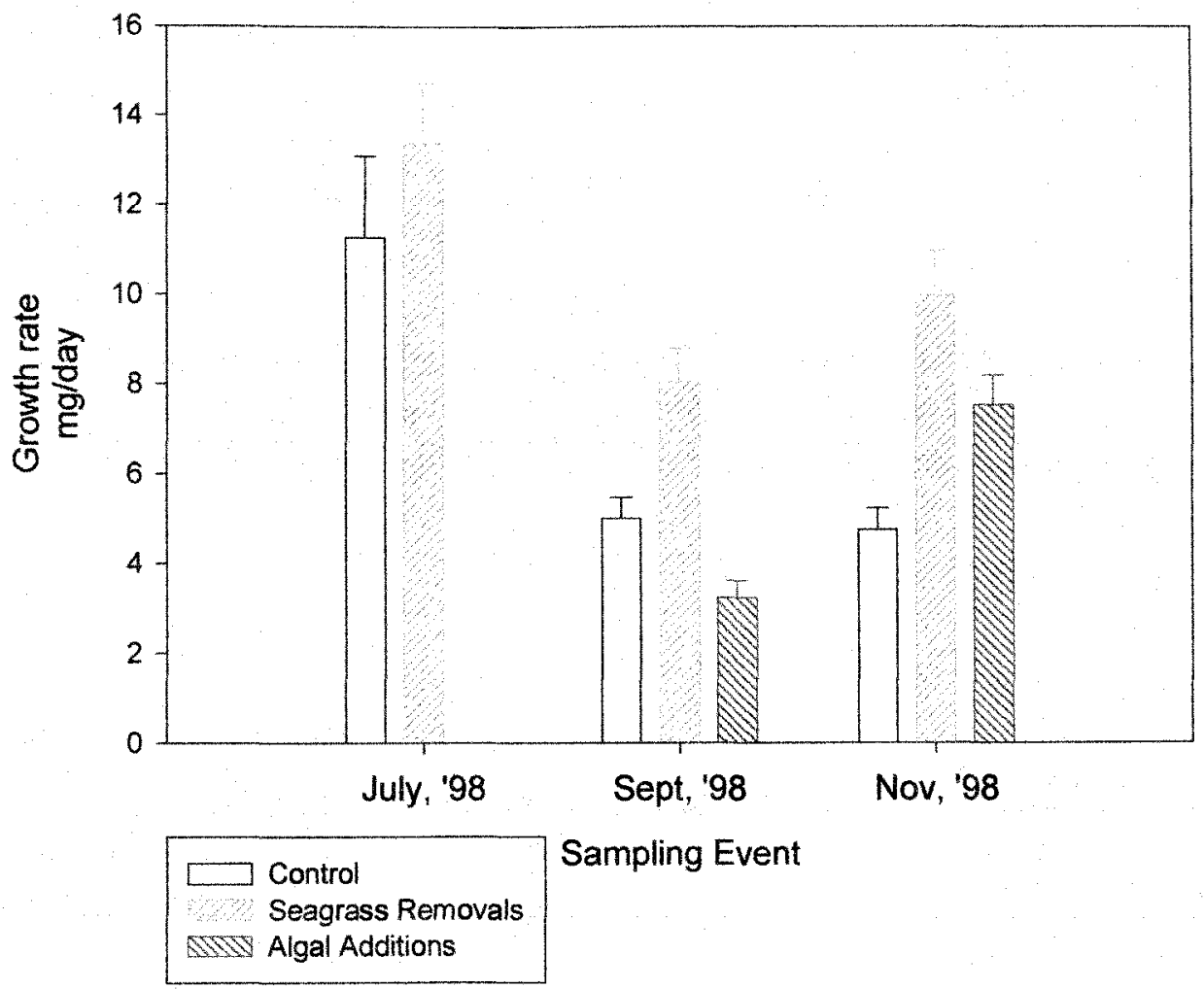

Figure 18. Average growth rates (mg/day) versus treatment, Halimeda incrassata. 


\begin{tabular}{c|ccccc} 
Source & $\begin{array}{c}\text { Sum of } \\
\text { Squares }\end{array}$ & df & $\begin{array}{c}\text { Mean } \\
\text { Square }\end{array}$ & F-ratio & p \\
\hline Treatment & 53.495 & 1 & 53.495 & 4.799 & $\mathbf{0 . 0 4 9}$ \\
Event & 118.498 & 2 & 59.249 & 5.315 & $\mathbf{0 . 0 2 2}$ \\
Treat*Event & 7.65 & 2 & 3.825 & 0.343 & 0.716 \\
Error & 133.762 & 12 & 11.147 & &
\end{tabular}

Table 6. ANOVA results for $\mathrm{mg}$ /day growth comparisons, Halimeda incrassata. Treatment Factors = Seagrass Removals and Controls; Event Factors = July, September and November sampling events.

\begin{tabular}{c|ccccc} 
Source & $\begin{array}{c}\text { Sum of } \\
\text { Squares }\end{array}$ & df & $\begin{array}{c}\text { Mean } \\
\text { Square }\end{array}$ & F-ratio & $\mathbf{p}$ \\
\hline Treatment & 60.767 & 2 & 30.384 & 10.377 & $\mathbf{0 . 0 0 2}$ \\
Event & 17.875 & 1 & 17.875 & 6.105 & $\mathbf{0 . 0 2 9}$ \\
Treat*Event & 15.384 & 2 & 7.692 & 2.627 & 0.113 \\
& & & & &
\end{tabular}

Table 7. ANOVA results for $\mathrm{mg} /$ day growth comparisons, Halimeda incrassata. Treatment Factors $=$ Seagrass Removals, Algal Additions and Controls; Event Factors = September and November sampling events. 


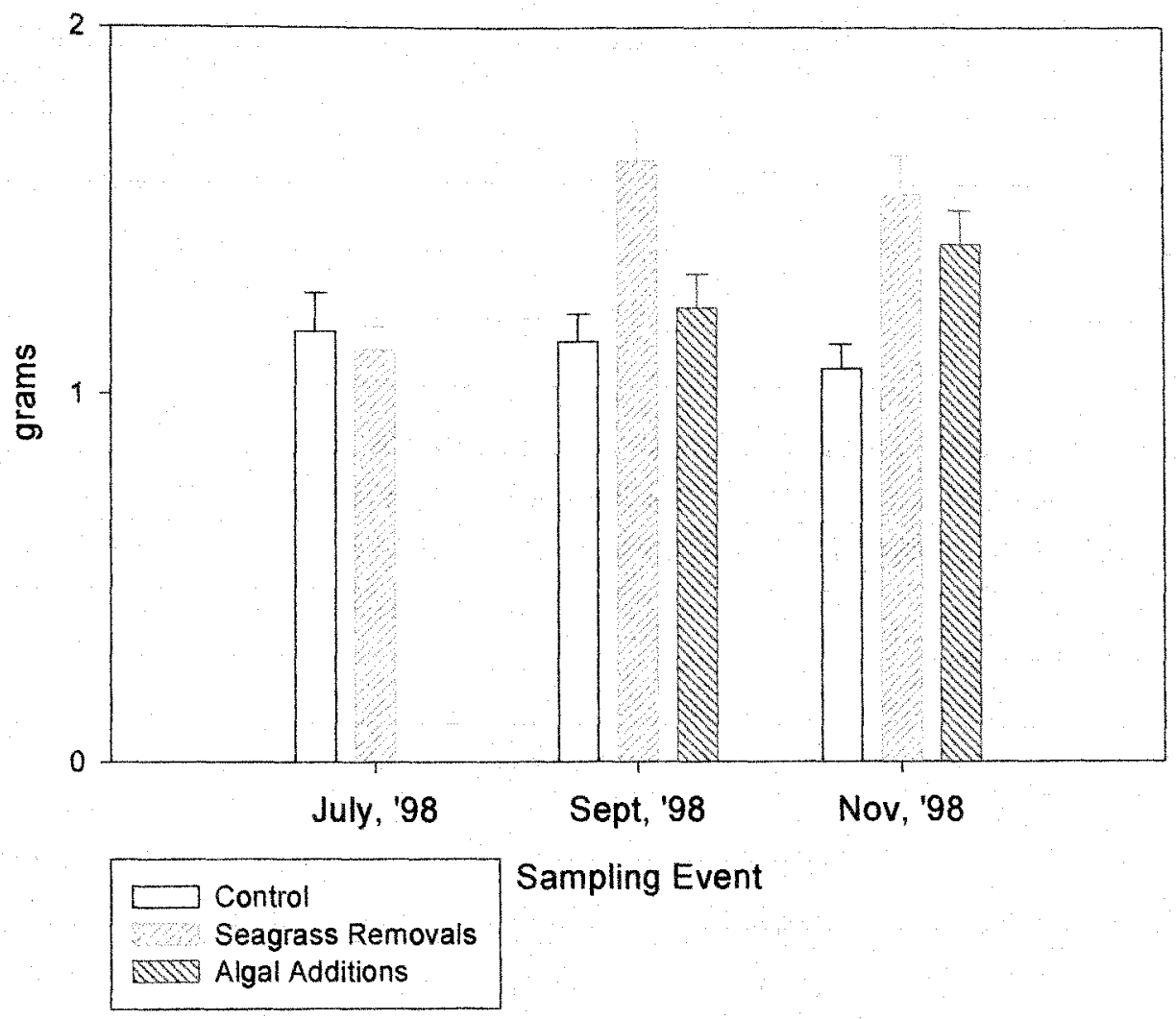

Figure 19. Average above-ground dry weight vs. treatment, Halimeda incrassata. 


\begin{tabular}{c|ccccc} 
Source & $\begin{array}{c}\text { Sum of } \\
\text { Squares }\end{array}$ & df & $\begin{array}{c}\text { Mean } \\
\text { Square }\end{array}$ & F-ratio & p \\
\hline Treatment & 0.419 & 1 & 0.419 & 7.493 & $\mathbf{0 . 0 1 8}$ \\
Event & 0.183 & 2 & 0.091 & 1.635 & 0.236 \\
Treat*Event & 0.284 & 2 & 0.142 & 2.540 & 0.120 \\
Error & 0.671 & 12 & 0.056 & &
\end{tabular}

Table 8. ANOVA results for average dry weight comparisons, $H$. incrassata.

Treatment Factors = Seagrass Removals and Controls;

Event Factors = July, September and November sampling events.

\begin{tabular}{c|ccccc} 
Source & $\begin{array}{c}\text { Sum of } \\
\text { Squares }\end{array}$ & df & $\begin{array}{c}\text { Mean } \\
\text { Square }\end{array}$ & F-ratio & $\mathbf{p}$ \\
\hline Treatment & 0.702 & 2 & 0.351 & 4.787 & $\mathbf{0 . 0 3 0}$ \\
Event & 0.000 & 1 & 0.000 & 0.000 & 0.993 \\
Treat*Event & 0.065 & 2 & 0.033 & 0.446 & 0.650 \\
Error & 0.880 & 12 & 0.073 & &
\end{tabular}

Table 9. ANOVA results for average dry weight comparisons, $H$. incrassata. Treatment Factors = Seagrass Removals, Algal Additions and Controls; Event Factors = September and November sampling events. 


\section{Thalassia testudinum Response}

In contrast to the effects of Thalassia testudinum density on Halimeda incrassata, growth rates of $T$. testudinum did not respond to manipulation of algal densities. There was, however, an increase in the average above-ground dry weight per shoot. Mean shoot production rates for Algal Removal, Algal Addition and Control plots were $1.607 \pm 0.14,1.413 \pm 0.18$ and $1.399 \pm 0.14$ $\mathrm{mg} \mathrm{day}^{-1}$ shoot $^{-1}$, respectively, (Figure 20), and were not found to be significantly different [Treatment main effect, $F=1.1 ;$ d.f. $=2,18 ; p=0.35$, Table 10]. The July, September and November mean production rates were $1.915 \pm 0.12,1.314 \pm 0.11$ and $1.191 \pm 0.09 \mathrm{mg} \mathrm{day}^{-1}$ shoot $^{-1}$, respectively. The July growth rates were significantly higher than those during subsequent sampling events [Event main effect, $F=12.49 ;$ d.f. $=2,18 ; p=0.00$, Table 10]. Leaf area production per shoot in Algal Removal, Algal Addition and Control plots averaged $0.435 \pm 0.042,0.415 \pm 0.039$ and $0.0 .405 \pm 0.038$ $\mathrm{cm}^{2}$ day $^{-1}$, respectively (Figure 21 ), and were not found to be significantly different [Treatment main effect, $F=1.14 ;$ d.f. $=2,18 ; p=0.34$, Table 11]. July, September and November sampling events averaged $0.547 \pm 0.026$, $0.379 \pm 0.019$ and $0.330 \pm 0.021 \mathrm{~cm}^{2} \mathrm{day}^{-1}$, respectively. Again, the July sampling event values were significantly higher than those of the other 
sampling events [Event main effect, $\mathrm{F}=18.96 ; \mathrm{d} . \mathrm{f}=2,18 ; \mathrm{p}=0.00$, Table 11].

A significant treatment $\mathrm{x}$ event interaction occurred $(\mathrm{p}=0.04)$ due to a reversal of trends in the data from September to November.

Mean total leaf dry weight values for Algal Removal, Algal Addition and Control plots were $0.064 \pm 0.005,0.049 \pm 0.003$ and $0.058 \pm 0.006 \mathrm{~g}$, respectively (Figure 22), and were found to be significantly different [Treatment main effect, $F=3.97 ;$ d.f. $=2,18 ; p=0.04$, Table 12]. The July, September and November mean values were $0.057 \pm 0.005,0.064 \pm 0.005$ and $0.049 \pm 0.004 \mathrm{~g}$, respectively. The September values were significantly higher than those of the November sampling event [Event main effect, $F=3.71 ;$ d.f. $=2,18 ; p=0.05$, Table 12].

\section{Potential Mechanisms of Interaction}

Averaged across all sampling events, leaf tissue carbon:nitrogen was decreased significantly in Algal Removal plots [Treatment main effect, $F=$ 3.3; d.f.= 2,18; $p=0.061$, Table 13]. Mean leaf tissue carbon:nitrogen ratios for Algal Removals, Algal Additions, and Controls were 27.46 \pm 0.48, 28.35 \pm 0.34 , and $29.25 \pm 0.49$, respectively (Figure 23 ). July, September, and November ratios averaged $29.87 \pm 0.31,28.01 \pm 0.93$, and $27.18 \pm 0.53$, 
respectively, and were found to significantly decrease from July to November [Event main effect, $F=6.9 ;$ d.f. $=2,18 ; p=0.006$, Table 13].

The percentage of canopy-level irradiance reaching the substrate did not differ significantly among treatments $[F=1.34 ;$ d.f. $=3,35 ; p=0.28$, Table 14]. Mean substrate-level irradiance for Algal Removals, Algal Additions, Seagrass Removals, and Controls was $93.1 \pm 4.7 \%, 94.6 \pm 5.5 \%, 99.7 \pm$ $2.1 \%$ and $83.7 \pm 8.7 \%$ of the paired canopy-level irradiance readings, respectively (Figure 24). 


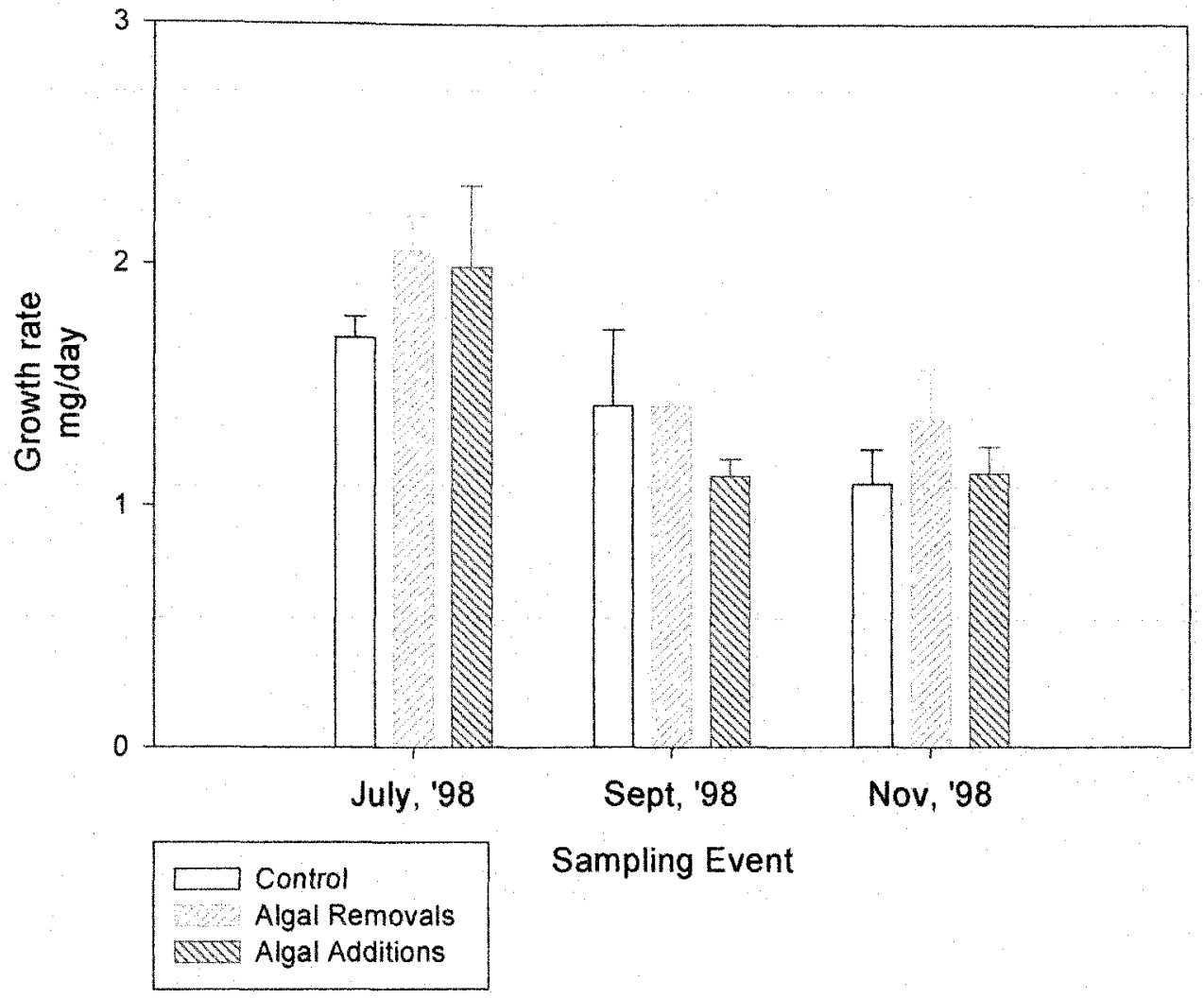

Figure 20. Average production rates (mg/day) vs treatment, Thalassia testudinum.

\begin{tabular}{c|ccccc} 
Source & $\begin{array}{c}\text { Sum of } \\
\text { Squares }\end{array}$ & df & $\begin{array}{c}\text { Mean } \\
\text { Square }\end{array}$ & F-ratio & $\mathbf{p}$ \\
\hline Treatment & 0.242 & 2 & 0.121 & 1.117 & 0.349 \\
Event & 2.703 & 2 & 1.351 & 12.494 & $\mathbf{0 . 0 0 0}$ \\
Treat* Event & 0.268 & 4 & 0.067 & 0.620 & 0.657 \\
Error & 1.947 & 18 & 0.108 & &
\end{tabular}

Table 10. ANOVA results for production rate comparisons, Thalassia testudinum. 


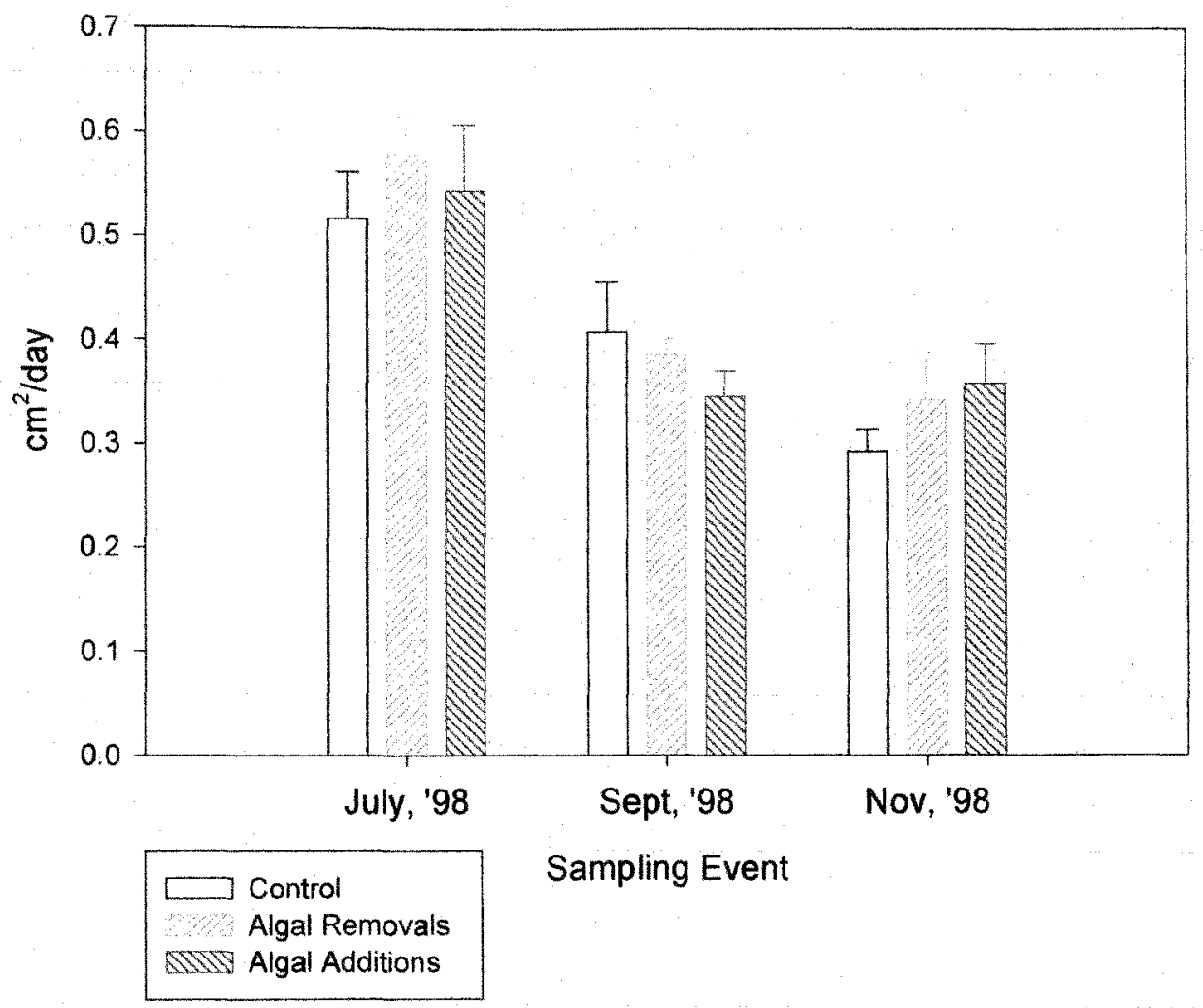

Figure 21. Leaf area production rates versus treatment, Thalassia testudinum.

\begin{tabular}{c|ccccc} 
Source & $\begin{array}{c}\text { Sum of } \\
\text { Squares }\end{array}$ & df & $\begin{array}{c}\text { Mean } \\
\text { Square }\end{array}$ & F-ratio & p \\
\hline Treatment & 0.076 & 2 & 0.038 & 1.144 & 0.340 \\
Event & 1.262 & 2 & 0.631 & 18.957 & $\mathbf{0 . 0 0 0}$ \\
Treat*Event & 0.418 & 4 & 0.105 & 3.143 & $\mathbf{0 . 0 4 0}$ \\
Error & 0.599 & 18 & 0.033 & &
\end{tabular}

Table 11. ANOVA results for leaf area production comparison, $T$. testudinum. 


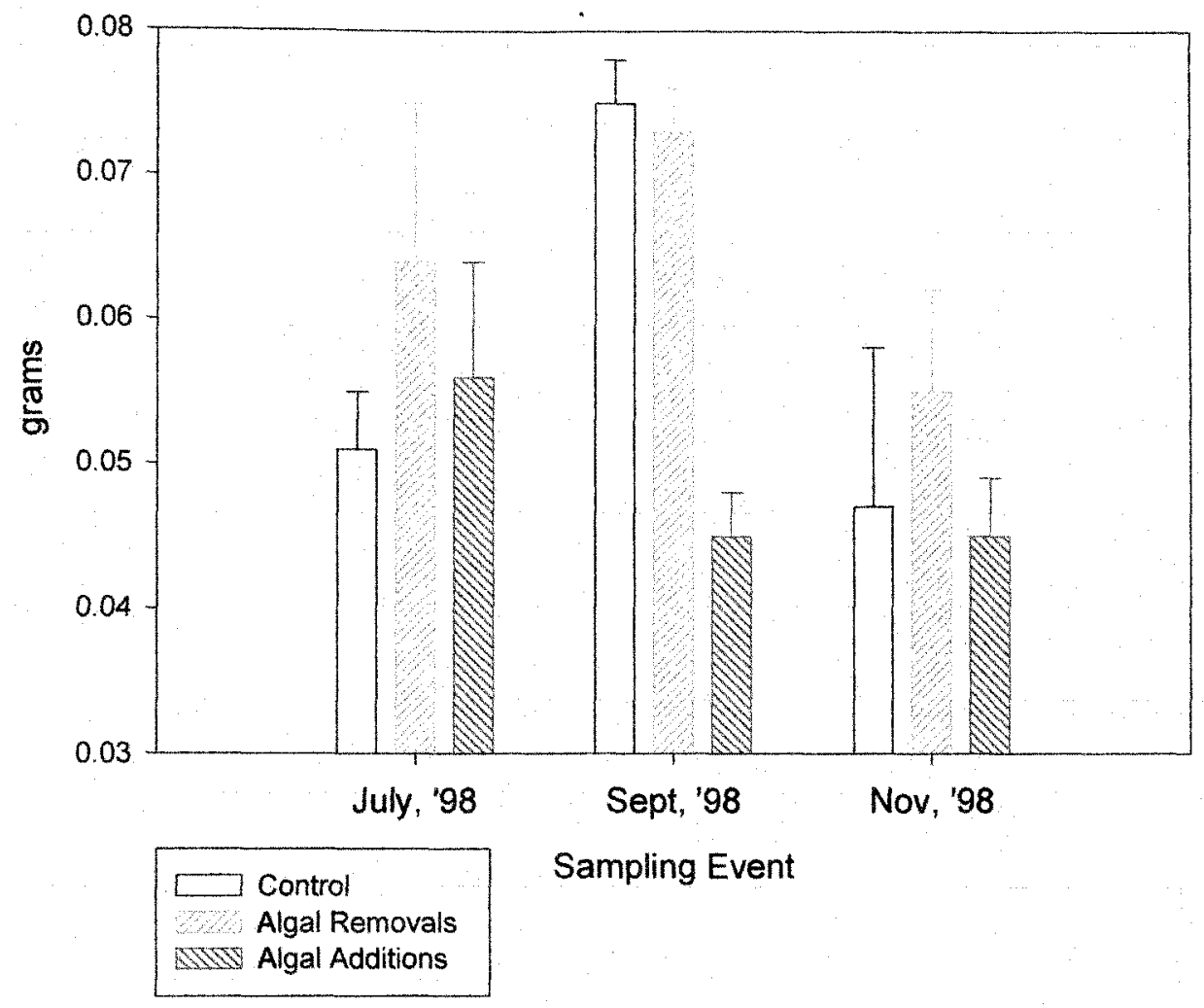

Figure 22. Average above-ground dry weight vs. treatment, Thalassia testudinum.

\begin{tabular}{c|ccccc} 
Source & $\begin{array}{c}\text { Sum of } \\
\text { Squares }\end{array}$ & df & $\begin{array}{c}\text { Mean } \\
\text { Square }\end{array}$ & F-ratio & $\mathbf{p}$ \\
\hline Treatment & 0.001 & 2 & 0.001 & 3.97 & $\mathbf{0 . 0 3 7}$ \\
Event & 0.001 & 2 & 0.001 & 3.71 & $\mathbf{0 . 0 4 5}$ \\
Treat*Event & 0.001 & 4 & 0.000 & 2.049 & 0.130 \\
Error & 0.002 & 18 & 0.000 & &
\end{tabular}

Table 12. ANOVA results for dry weight per shoot comparisons, $T$. testudinum. 


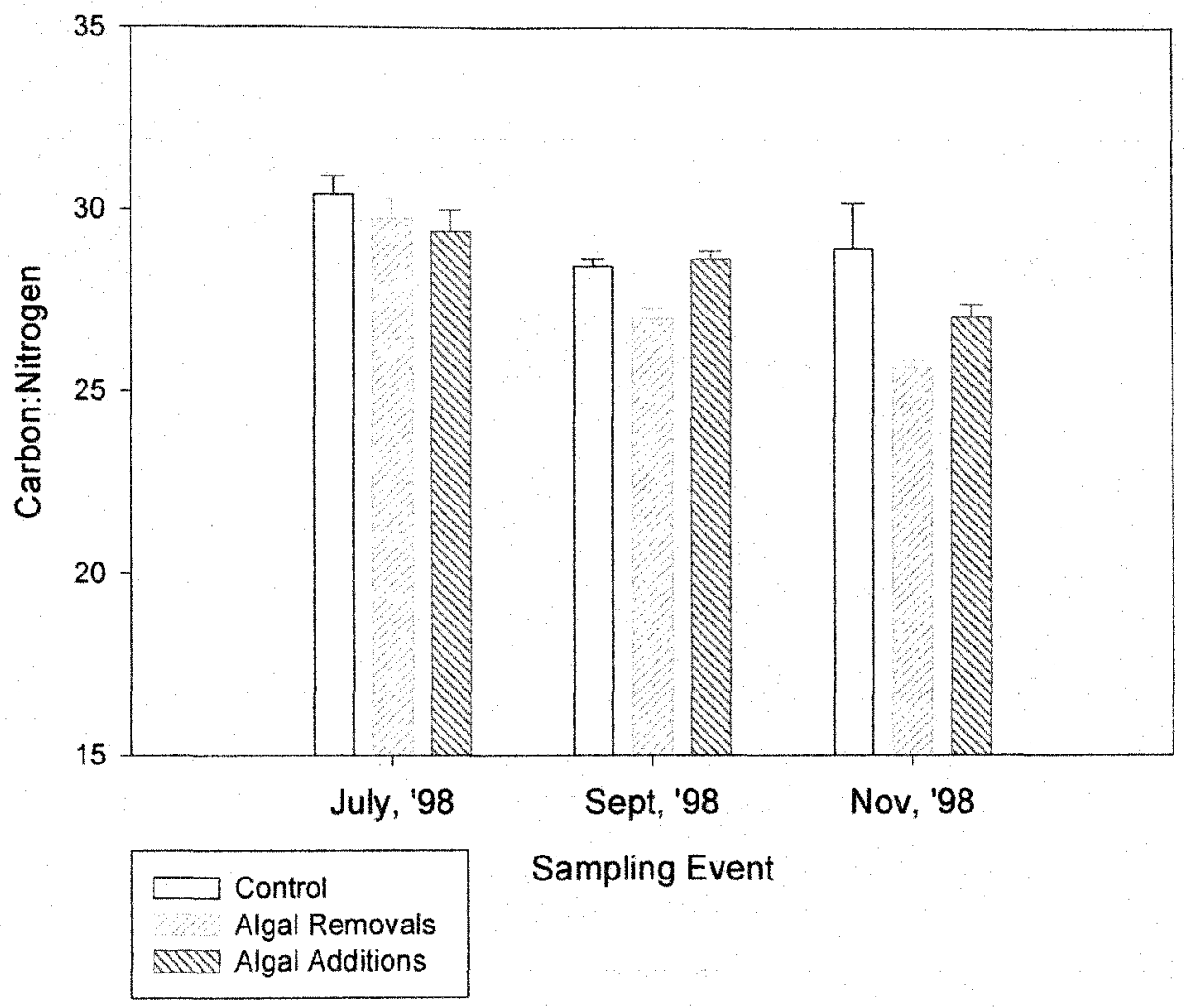

Figure 23. Leaf tissue carbon:nitrogen versus treatment, Thalassia testudinum.

\begin{tabular}{c|ccccc} 
Source & $\begin{array}{c}\text { Sum of } \\
\text { Squares }\end{array}$ & df & $\begin{array}{c}\text { Mean } \\
\text { Square }\end{array}$ & F-ratio & p \\
\hline Treatment & 14.901 & 2 & 7.451 & 3.269 & $\mathbf{0 . 0 6 1}$ \\
Event & 31.444 & 2 & 15.722 & 6.899 & $\mathbf{0 . 0 0 6}$ \\
Treat*Event & 8.218 & 4 & 2.054 & 0.901 & 0.484 \\
Error & 41.021 & 18 & 2.279 & &
\end{tabular}

Table 13. ANOVA results for $\mathrm{C}: \mathrm{N}$ leaf tissue comparisons, Thalassia testudinum. 


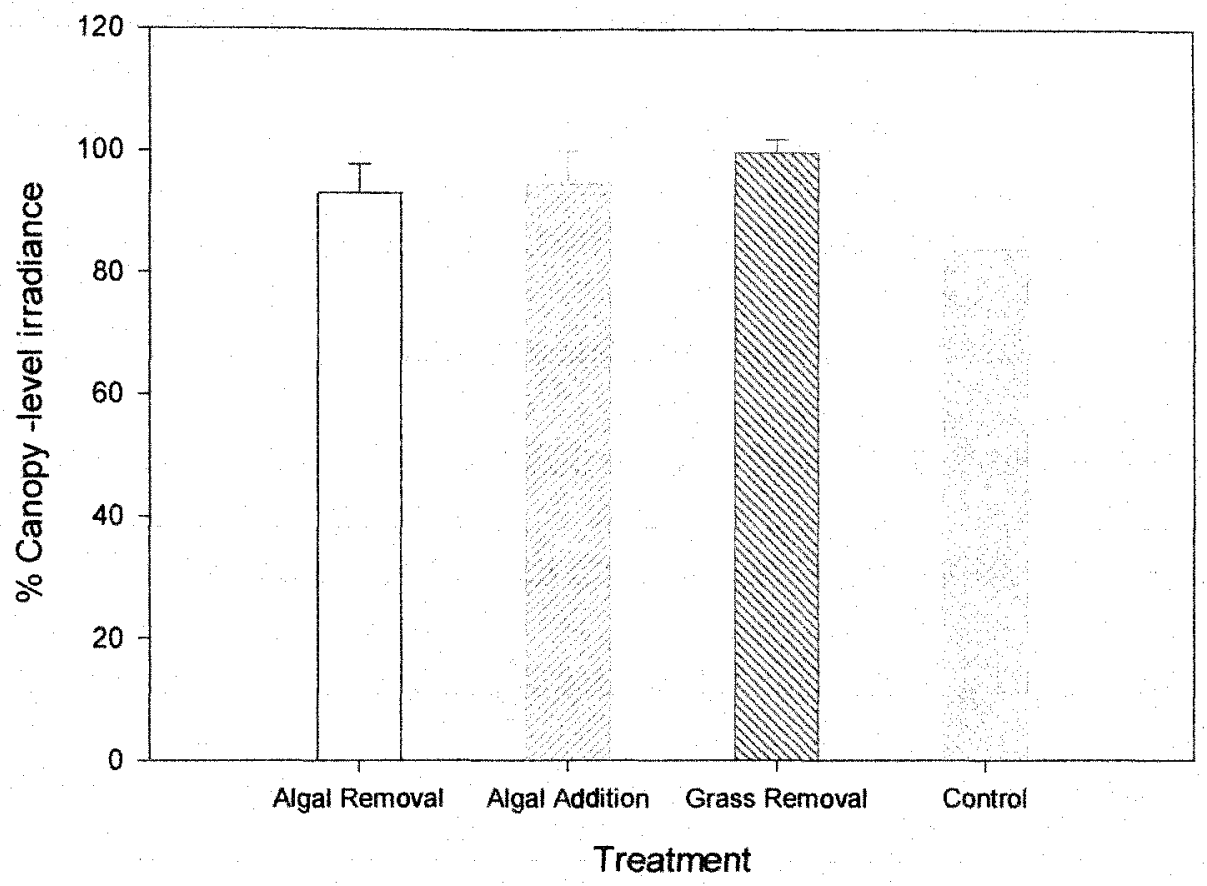

Figure 24. Average canopy-level and substrate-level irradiance (as a percentage of canopy level) versus treatment.

\begin{tabular}{c|ccccc} 
Source & $\begin{array}{c}\text { Sum of } \\
\text { Squares }\end{array}$ & df & $\begin{array}{c}\text { Mean } \\
\text { Square }\end{array}$ & F-ratio & p \\
\hline Treatment & 0.120 & 3 & 0.04 & 1.34 & 0.279 \\
Residual & 0.959 & 32 & 0.03 & & \\
& & & & & \\
Total & 1.079 & 35 & & &
\end{tabular}

Table 14. ANOVA results for sediment-level irradiance comparisons. 


\section{DISCUSSION}

Thalassia testudinum and Halimeda incrassata growth rates were consistent with those reported in the literature (Table 1; Wefer, 1980). The algae contributes a significant portion of the organic production (Table 5) in the area. The relative organic production data can be used to create largescale production estimates once paired with spatial abundance data in

Chapter 2. Simultaneous growth measurement methodologies for the seagrass and algae were demonstrated to be effective. They provided acceptable measures of net production; but more importantly, the methods were proven to detect both seasonal trends and treatment effects.

Algal growth rates and average above-ground dry weights were significantly higher in Seagrass Removal plots, and seagrass average aboveground dry weights in Algal Removal plots were significantly higher than those of Algal Addition plots. These results match those predicted by a competitive interaction hypothesis, except for a lack of seagrass growth rate responses. The results show with highest confidence that moderate densities of Thalassia testudinum negatively affect the size and growth rate of Halimeda incrassata. 
A competitive interaction between two species may result in the reduced colonization ability, longevity, growth, or reproductive success of one species when in the presence of a minimum density of the other species. In this study, I evaluated only changes in growth as a measure of competitive interaction within a mature seagrass community. The possible effects on recruitment of either species was not evaluated, nor were possible effects on longevity or reproductive success. Williams (1990) found that rhizophytic macroalgae facilitate the recolonization of seagrasses, but the effect of seagrass densities on macroalgal recruitment is unknown.

The study area was a seagrass meadow of medium seagrass and algal densities (Chapter 2). The effects of resource competition are expected to weaken in areas of lower densities, where levels of stress are often more important than resource availability. Interspecific interactions likely have lesser effects in areas of higher seagrass or macroalgal densities as well, where intraspecific competition may take on more importance.

Because the study ran from July through November, there existed a potential for a seasonal effect on seagrass and algal sizes and productivities. The effect was demonstrated in the data. Algal growth rates were significantly higher in July than in the following months. Seagrass production rates were significantly higher in July as well. Seagrass average above- 
ground dry weights were significantly higher in September, which could be as result of the significantly higher growth rates in July.

I considered two possible mechanisms of the competitive interaction: nitrogen and light limitation. Leaf tissue carbon:nitrogen was significantly lower in Algal Removal plots at $\mathrm{p}=0.061$, which indicates an increase in nitrogen availability. Light was not demonstrated to significantly increase in Seagrass Removal plots; however, there was low power in the statistical analysis.

Light availability and leaf tissue carbon:nitrogen vary seasonally, and are interrelated. Light availability was not measured over time within this study, but from the seasonal growth response in both species I assume that light availability decreased over the course of the study. Leaf tissue carbonnitrogen tends to peak in the summer months as high productivity results in nutrient depletion (Fourqurean et al., 1997), which corresponds to its covariance with light availability. As light availability increases, leaf tissue nitrogen concentrations decrease as the nitrogen becomes more limiting (Abal et al., 1994). In agreement with these findings, carbon:nitrogen decreased significantly over the course of the study.

If one assumes that light availability increased in Algal Removal plots, then carbon:nitrogen values from these treatments should be higher if no 
competitive interaction exists. In other words, there should be lower nitrogen concentrations in the seagrass leaves due to increased growth; which, while not significant, did occur in each Algal Removal treatment in each sampling event. Instead, they were significantly lower at $p=0.061$, suggesting that nitrogen may play an important role in the interaction.

Competition may be defined as a negative impact of one species on another's ecological fitness. For this to occur, one species either affects resource acquisition abilities of the other, or affects some system-level "bottom-up" or "top-down" control that acts independently of growth resources. In a system where top-down control mechanisms are important in dictating community composition, changes in herbivory rates depending on the presence or absence of one species may appear to be a competitive interaction. For example, in seagrass removal plots, small herbivorous fishes may feed less on the macroalgae because of the limited protective cover of seagrass blades. This could result in increased growth or biomass of algal samples in seagrass removal treatments, and could be labelled competition. Because this study did not investigate these potential effects of species removals, they must be considered as possible mechanisms of the interaction. 


\section{CONCLUSIONS}

Chapter 1 introduced two study objectives. First, I wanted to

document large and small-scale spatial patterns in neotropical macrophyte distributions and abundances based on competitive interaction hypotheses from other studies. Negative correlations in species abundances were found over a regional scale between seagrasses and rhizophytic macroalgae of the order Caulerpales. Small-scale spatial patterns in macrophyte densities around a migrating disturbance did not match models of ecosystem development or of blowout recolonization. Second, I directly tested for a competitive interaction between a representative of the rhizophytic macroalgae, Halimeda incrassata, and the dominant seagrass, Thalassia testudinum. I found sufficient evidence of a competitive interaction within a mature seagrass community by measuring growth responses of both species after density manipulations. I also documented relative organic production by both species within the same time and space which yields relative aerial production estimates. Nitrogen limitation may be an important underlying mechanism to the interaction demonstrated; however, other possibilities, including changes in herbivory, may also explain growth responses that were 
found. In this way, both study objectives were accomplished, and agreed with the hypotheses presented in the Introduction. 


\section{References}

Bach, S.D. 1979. Standing crop, growth and productivity of calcareous siphonales (Chlorophyta) in a south Florida lagoon. Bulletin of Marine Science 29(2): 191-201.

Braun-Blanquet, 1972. The basis of social life among plants. Pages 31-32 in Fuller, G.D. and H.S. Conard (eds.). Plant Sociology: The study of plant communities. Hafner Publishing, New York.

Clifton, K.E. 1997. Mass spawning by green algae on coral reefs. Science 275: $1116-1118$.

Cox, P.A. and P.B. Tomlinson. 1988. Pollination ecology of a seagrass, Thalassia testudinum (Hydrocharitaceae), in St. Croix. American Journal of Botany 75(7): 958-965.

Cutler, J.L. 1998. Clonal diversity in Thalassia testudinum populations in Rabbit Key Basin, Florida Bay. Masters Thesis, Florida International University, Miami, Florida. 52 pp.

den Hartog, C. 1971. The dynamic aspect in the ecology of sea-grass communities. Thalassia Jugoslavica 7(1): 101-112. 
Duarte, C.M., Marbá, N., Agawin, N., Cebrián, J., Enríquez, S., Fortes, M.D., Gallegos, M.E., Merino, M., Olesen, B., Snad-Jensen, K., Uri, J., and J. Vermaat. 1994. Reconstruction of seagrass dynamics: Age determinations and associated tools for the seagrass ecologist. Marine Ecology Progress Series 107: 195-209.

Durako, M.J. and M.D. Moffler. 1985. Observations on the reproductive ecology of Thalassia testudinum (Hydrocharitaceae). III. Spatial and temporal variations in reproductive patterns within a seagrass bed. Aquatic Botany 22: 265-276.

Durako, M.J. and M.D. Moffler. 1987. Factors affecting the reproductive ecology of Thalassia testudinum (Hydrocharitaceae). Aquatic Botany 27: 79-95.

EPA. 1995. Water Quality Protection Program for the Florida Keys National Marine Sanctuary. Phase III Report. Implementation of Plan for Water Quality Monitoring and Research Programs submitted to the Environmental Protection Agency under Work Assignment 1, Contract No. 68-C2-0134. Battelle Ocean Sciences, Duxbury, MA and Continental Shelf Associates, Inc., Jupiter, FL.

Fong, P. and M.A. Harwell. 1994. Modeling seagrass communities in tropical and subtropical bays and estuaries: a mathematical model synthesis of current hypotheses. Bulletin of Marine Science 54(3): 757-781. 
Fourqurean, J.W., Zieman, J.C. and G.V.N. Powell. 1992a. Relationships between porewater nutrients and seagrasses in a subtropical carbonate environment. Marine Biology 114: 57-65.

Fourqurean, J.W., J.C. Zieman and G.V.N. Powell. 1992b. Phosphorus limitation of primary production of Florida Bay: Evidence from the $\mathrm{C}: \mathrm{N}: \mathrm{P}$ ratios of the dominant seagrass Thalassia testudinum. Limnology and Oceanography 37(1): 162-171.

Fourqurean, J.W., R.D. Jones and J.C. Zieman. 1993. Processes influencing water column nutrient characteristics and phosphorus limitation of phytoplankton biomass in Florida Bay, FL, USA: Inferences from spatial distributions. Estuarine, Coastal and Shelf Science 36: 295314.

Fourqurean, J.W., Powell, G.V.N., Kenworthy, W.J. and J.C. Zieman. 1995. The effects of long-term manipulation of nutrient supply on competition between the seagrasses Thalassia testudinum and Halodule wrightii in Florida Bay. Oikos 72: 349-358.

Fourqurean, J.W., T.O. Moore, B. Fry and J.T. Hollibaugh. 1997. Spatial and temporal variation in $\mathrm{C}: \mathrm{N}: \mathrm{P}$ ratios, $\mathrm{d}^{15} \mathrm{~N}$, and $\mathrm{d}^{13} \mathrm{C}$ of eelgrass (Zostera marina L.) as indicators of ecosystem processes, Tomales Bay, CA, USA. Marine Ecology Progress Series 157: 147-157. 
Freile, D. and L. Hillis. 1997. Carbonate production by Halimeda incrassata in a land proximal lagoon, Pico Feo, San Blas, Panama. Proceeds of the 8th International Coral Reef Symposium 1: 767-772.

Gallegos, M.E., Merino, M., Marbá, N. and C.M. Duarte. 1993. Biomass and dynamics of Thalassia testudinum in the Mexican Caribbean: elucidating rhizome growth. Marine Ecology Progress Series 95: 185192.

Gallegos, M.E., Merino, M., Rodriguez, A., Marbá, N. and C.M. Duarte. 1994. Growth patterns and demography of pioneer Caribbean seagrasses Halodule wrightii and Syringodium filiforme. Marine Ecology Progress Series 109: 99-104.

Gopal, B. and U. Goel. 1993. Competition and allelopathy in aquatic plant communities. The Botanical Review 59(3): 155-210.

Hemminga, M.A., Harrison, P.G. and F. van Lent. 1991. The balance of nutrient losses and gains in seagrass meadows. Marine Ecology Progress Series 71: 85-96.

Hillis-Collinvaux, Llewellya. 1980. Ecology and taxonomy of Halimeda: Primary producers of coral reefs. Advances in Marine Biology 17: $1-327$. 
Holmquist, J.G. 1997. Disturbance and gap formation in a marine benthic mosaic: Influence of shifting macroalgal patches on seagrass structure and mobile invertabrates. Marine Ecology Progress Series 158: 121130.

Johnson, E.A. and S.L. Williams. 1982. Sexual reproduction in seagrasses: Reports for five Caribbean species with details for Halodule wrightii Aschers. and Syringodium filiforme Kütz. Caribbean Journal of Science 18(1): 61-70.

Kirkman, H. 1985. Community structure in seagrasses in southern western Australia. Aquatic Botany 21: 363-375.

Klein, C.J. III, and S.P. Orlando, Jr. 1994. A spatial framework for waterquality management in the Florida Keys National Marine Sanctuary. Bulletin of Marine Science 54(3): 1036-1044.

Larkum, A.W.D. and P.L. James. 1996. Towards a model for inorganic carbon uptake in seagrasses involving carbonic anhydranase. Seagrass Biology: Proceedings of an International Workshop, Rottnest Island, Western Australia. pp. 191-196.

Lewis, R.R. III and R.C. Phillips. 1980. Occurrence of seeds and seedlings of Thalassia testudinum Banks ex König in the Florida Keys, U.S.A. Aquatic Botany 9: 377-380. 
Littler, D. 1980 . Sources of variability in macroalgal primary productivity. Aquatic Botany 8: 141-156.

McRoy, C.P. and D.S. Lloyd. 1981. Comparative function and stability of macrophyte-based ecosystems. Pages 473-489 in A.R. Longhurst, editor. Analysis of marine ecosystems. Academic Press, London, England.

Moffler, M.D., and M.J. Durako. 1987. Reproductive biology of the tropicalsubtropical seagrasses of the southeastern United States. Florida Marine Research Publications 42: 77-88.

Multer, H.G. 1988. Growth rate, ultrastructure and sediment contribution of Halimeda incrassata and Halimeda monile, Nonsuch and Falmouth Bays, Antigua, W.I. Coral Reefs 6: 179-186.

Odum, E.P. 1969. The strategy of ecosystem development. Science 164: 262-269.

Patriquin, D.G. 1972. The origin of nitrogen and phosphorus for growth of the marine angiosperm Thalassia testudinum. Marine Biology 15(1): 3546. 
Patriquin, D.G. 1975. "Migration" of blowouts in seagrass beds at Barbados and Carriacou, West Indies, and its ecological and geological implications. Aquatic Botany 1: 163-189.

Phillips, R.C., C. McMillan, and K.W. Bridges. 1981. Phenology and reproductive physiology of Thalassia testudinum from the western tropical Atlantic. Aquatic Botany 11: 263-277.

Quispel, A. (Ed.) 1974. The Biology of Nitrogen Fixation. North-Holland Publishing Col., Amsterdam.

Rejmanek, M. and J. Leps. 1996. Negative associations can reveal interspecific competition and reversal of competitive hierarchies during succession. Oikos 76(1): 161-168.

Schoener, T.W. 1983. Field experiments on interspecific competition. The American Naturalist 122(2): 240-285.

Short, F.T. and S. Wyllie-Echeverria. 1996. Natural and human-induced disturbance of seagrasses. Environmental Conservation 23(1): 17-27.

Stapel, J., Aarts, T.L., van Duynhoven, B.H.M., de Groot, J.D., van den Hoogen, P.H.W. and M.A. Hemminga. 1996. Nutrient uptake by leaves and roots of the seagrass Thalassia hemprichii in the Spermonde Archipelago, Indonesia. Marine Ecology Progress Series 134: 195-206. 
Thomas, L.P., Moore, D.R., and R.C. Work. 1961. Effects of Hurricane Donna on the turtle grass beds of Biscayne Bay, Florida. Bulletin of Marine Science of the Gulf and Caribbean 11(2): 191-197.

Tilman, D. 1994. Competition and biodiversity in spatially structured habitats. Ecology 75(1): 2-16.

Tomlinson, P.B. and G.A. Vargo. 1966. On the morphology and anatomy of turtle grass, Thalassia testudinum (Hydrocharitaceae). I. Vegetative morphology. Bulletin of Marine Science 16(4): 749-761.

Turner, T. 1983. Facilitation as a successional mechanism in a rocky intertidal community. American Naturalist 121: 729-738.

van Tussenbroek, B.I. 1995. Thalassia testudinum leaf dynamics in a Mexican Caribbean coral reef lagoon. Marine Biology 122: 33-40.

Wanless, H.R. 1981. Fining-upwards sedimentary sequences generated in seagrass beds. Journal of Sedimentary Petrology 51(2): 445-454.

Watson, D.F. 1992. Contouring: a guide to the analysis and display of spatial data. Pergammon Press, New York. 321 pp.

Wefer, G. 1980. Carbonate production by algae Halimeda, Penicillus and Padina. Nature 285: 323-324. 
Williams, S.L. 1984. Uptake of sediment ammonium and translocation in a marine green macroalga Caulerpa cupressoides. Limnology and Oceanography 29: 374-379.

Williams, S.L. 1985. Factors affecting seagrass recolonization. Estuaries 8: $16 \mathrm{~A}$.

Williams, S.L. 1987. Competition between the seagrasses Thalassia testudinum and Syringodium filiforme in a Caribbean lagoon. Marine Ecology Progress Series 35: 91-98.

Williams, S.L. 1988. Disturbance and recovery of a deepwater Caribbean seagrass bed. Marine Ecology Progress Series 42: 63-71.

Williams, S.L. 1990. Experimental studies of Caribbean seagrass bed development. Ecological Monographs 60: 449-469.

Williams, S.L. and W.H. Adey. 1983. Thalassia testudinum Banks ex König seedling success in a coral reef microcosm. Aquatic Botany 16: 181188.

Witz, M.J.A. and C.J. Dawes. 1995. Flowering and short shoot age in three Thalassia testudinum meadows off west-central Florida. Botanica Marina 38: 431-436. 
Zieman, J.C. 1974. Methods for the study of the growth and production of turtle grass, Thalassia testudinum Konig. Aquaculture 4: 139-143.

Zieman, J.C. 1975. Quantitative and dynamic aspects of the ecology of turtle grass, Thalassia testudinum. Estuarine Research 1: 541-562.

Zieman, J.C. 1982. The ecology of the seagrasses of south Florida: a community profile. U.S. Fish and Wildlife Services, Office of Biological Services, Washington, D.C. FWS/OBS-82/25. 158 pp.

Zieman, J.C. and R.T. Zieman. 1989. The ecology of the seagrass meadows of the west coast of Florida: a community profile. U.S. Fish and Wildlife Services, Office of Biological Services Rep. 85(7.25). $155 \mathrm{pp}$.

Zieman, J.C., Fourqurean J.W. and R.L. Iverson. 1989. Distribution, abundance and productivity of seagrasses and macroalgae in Florida Bay. Bulletin of Marine Science 44: 292-311. 